\title{
Review of Microwaves Techniques for Breast Cancer Detection
}

\author{
Maged A. Aldhaeebi ${ }^{1}$, Khawla Alzoubi ${ }^{2}$, Thamer S. Almoneef ${ }^{3}$, Saeed M. Bamatraf ${ }^{1}$ (D), \\ Hussein Attia ${ }^{4, *}$ and Omar M. Ramahi ${ }^{1}$ (D) \\ 1 Electrical and Computer Engineering, University ofWaterloo, Waterloo, ON N2L3G1, Canada; \\ maldhaee@uwaterloo.ca (M.A.A.); smbamatr@uwaterloo.ca (S.M.B.); oramahi@uwaterloo.ca (O.M.R.) \\ 2 Community College of Qatar, Doha 7344, Qatar; Khawla.Alzoubi@ccq.edu.qa \\ 3 Electrical Engineering Department, College of Engineering, Prince Sattam Bin Abdulaziz University, \\ Al-Kharj 11942, Saudi Arabia; T.almoneef@psau.edu.sa \\ 4 Electrical Engineering Department, King Fahd University of Petroleum and Minerals (KFUPM), \\ Dhahran 31261, Saudi Arabia \\ * Correspondence: hattia@kfupm.edu.sa
}

Received: 10 February 2020; Accepted: 15 April 2020; Published: 22 April 2020

\begin{abstract}
Conventional breast cancer detection techniques including X-ray mammography, magnetic resonance imaging, and ultrasound scanning suffer from shortcomings such as excessive cost, harmful radiation, and inconveniences to the patients. These challenges motivated researchers to investigate alternative methods including the use of microwaves. This article focuses on reviewing the background of microwave techniques for breast tumour detection. In particular, this study reviews the recent advancements in active microwave imaging, namely microwave tomography and radar-based techniques. The main objective of this paper is to provide researchers and physicians with an overview of the principles, techniques, and fundamental challenges associated with microwave imaging for breast cancer detection. Furthermore, this study aims to shed light on the fact that until today, there are very few commercially available and cost-effective microwave-based systems for breast cancer imaging or detection. This conclusion is not intended to imply the inefficacy of microwaves for breast cancer detection, but rather to encourage a healthy debate on why a commercially available system has yet to be made available despite almost 30 years of intensive research.
\end{abstract}

Keywords: microwaves; breast cancer imaging; dielectric properties of tissues; microwave imaging; image reconstruction

\section{Introduction}

Breast cancer is one of the most common types of cancer among women worldwide. In 2019, the American Cancer Society reported that more than 40,000 women died due to breast cancer and estimated that more than 260,000 new cases of invasive breast cancer will be diagnosed among women in the U.S. [1]. The same report also confirmed the deaths of 500 men due to breast cancer and estimated that nearly 2700 cases more will be diagnosed in male patients. The mortality rate is higher for men than women due to a lack of awareness, as they may not guess that a lump is actually breast cancer. Detecting breast cancer during its early stages of development is a fundamental factor for successful treatment [1]. The most common clinical imaging and detection modalities used for breast cancer detection are: X-ray mammography, magnetic resonance imaging (MRI), and ultrasound scanning [2].

Mammography is the only USFDA approved exam to be used for screening breast cancer in women with no prior symptoms. Mammography, however, has recently been subjected to immense scrutiny because of relatively high false negative and false positive results that can prove to be 
emotionally disruptive to the patient's life [3]. Furthermore, women who use mammography as a screening test have a higher chance of developing cancer because of the ionizing radiation associated with X-rays $[4,5]$. Physical discomfort to women undergoing mammography is another drawback of this imaging technique [6]. Ultrasound screening is another technique of breast cancer detection where sound waves are transmitted through a transducer, which sends pulses into the breast and detects echoes from inside the breast; these echoes are used to form ultrasound images. However, ultrasound is not advantageous for breast imaging as it exhibits low resolution due to it not being able to distinguish between malignant and benign breast tumours $[7,8]$. MRI is highly sensitive in detecting invasive and small abnormalities compared with mammography and ultrasound techniques and can be used effectively for patients with dense breasts. Testing using MRI, however, is relatively expensive. Additionally, in MRI, inadequate breast positioning can cause unsuccessful detection [9].

The disadvantages and limitations of the current clinical detection techniques motivated researchers to investigate and develop new imaging techniques based on microwaves $[10,11]$. The concept of using microwaves for breast cancer detection received significant attention and extensive investigation from several research groups because of several advantages including low cost, having harmless radiation, and ease of use compared with current techniques, as shown in Table 1 [12,13]. In addition, the microwave imaging (MI) technique provides better sensitivity and the ability to detect small breast tumours because it is based on the electrical properties' contrast between normal and tumours breast tissues [13].

Table 1. A comparison between microwave imaging (MI) and other breast cancer detection techniques.

\begin{tabular}{llll}
\hline Mammography & Ultrasound & MRI & Microwave Imaging \\
\hline -Ionizing radiation & -Low sensitivity & -Very expensive & -Non-ionizing \\
\hline $\begin{array}{l}\text {-Uncomfortable: involves } \\
\text { breast compression }\end{array}$ & -Higher cost than X-rays & $\begin{array}{l}\text {-Some types of breast } \\
\text { cancers cannot be detected }\end{array}$ & $\begin{array}{l}\text {-Non-invasive } \\
\text {-Inexpensive }\end{array}$ \\
\hline $\begin{array}{l}\text {-Sensitivity decreases } \\
\text { with high density tissue }\end{array}$ & $\begin{array}{l}\text {-A highly experienced } \\
\text { operator is needed to } \\
\text { perform an examination }\end{array}$ & $\begin{array}{l}\text {-Inadequate positioning } \\
\text { can cause an } \\
\text { unsuccessful detection }\end{array}$ & -Comfortable \\
\hline
\end{tabular}

The specific aim of this paper is to provide a thorough review of the microwave-based imaging techniques developed for breast cancer detection. The review focuses on the two types of MI, namely microwave tomography and radar-based techniques. A survey of the imaging algorithms, imaging methods, imaging system, and clinical prototype system is provided.

The other objective of this paper is to provide a chronological summary of research related to microwaves for breast cancer detection in order to highlight the challenges and limitations faced and to accentuate the incremental improvements accomplished over the years. Specifically, the following chronological summaries are provided: (1) a chronological summary of studies and measurements of the dielectric properties of human female breast tissues; (2) a chronological summary of research related to microwave tomographic imaging methods and systems; (3) a chronological summary of research related to radar-based methods and systems. Compared to other similar works, the presented review paper is a unique comprehensive chronological summary that covers all aspects of MI for breast cancer detection citing and discussing approximately 300 references. Additionally, this work addresses the challenges (i.e., sensitivity, cost, harmful radiation, and inconveniences to the patients) that the current detection systems are facing with a detailed discussion of various software algorithms, antenna and sensors types, and operating frequencies.

\section{Microwave Dielectric Properties of Breast Tissues}

In recent years, microwaves have emerged as a potential technique for breast cancer detection that avoids the discomfort, high-risk, and costs associated with X-rays and MRI. The fundamental premise of microwave detection is the sharp contrast in the dielectric (electrical) properties of cancerous 
tumours in comparison to healthy tissues. To avoid all the limitations mentioned in the current techniques, researchers have shifted their attention to an alternative modality based on microwaves. MI is a technique used to detect hidden or embedded objects inside a medium using microwaves. An MI system is based on two main parts: (i) hardware (antenna) responsible for illuminating and collecting microwave signals reflected from the illuminated object under test such as breast tissues; (ii) software or post-processing algorithms that are responsible for reconstructing an image of the target object as shown in Figure 1 [8].

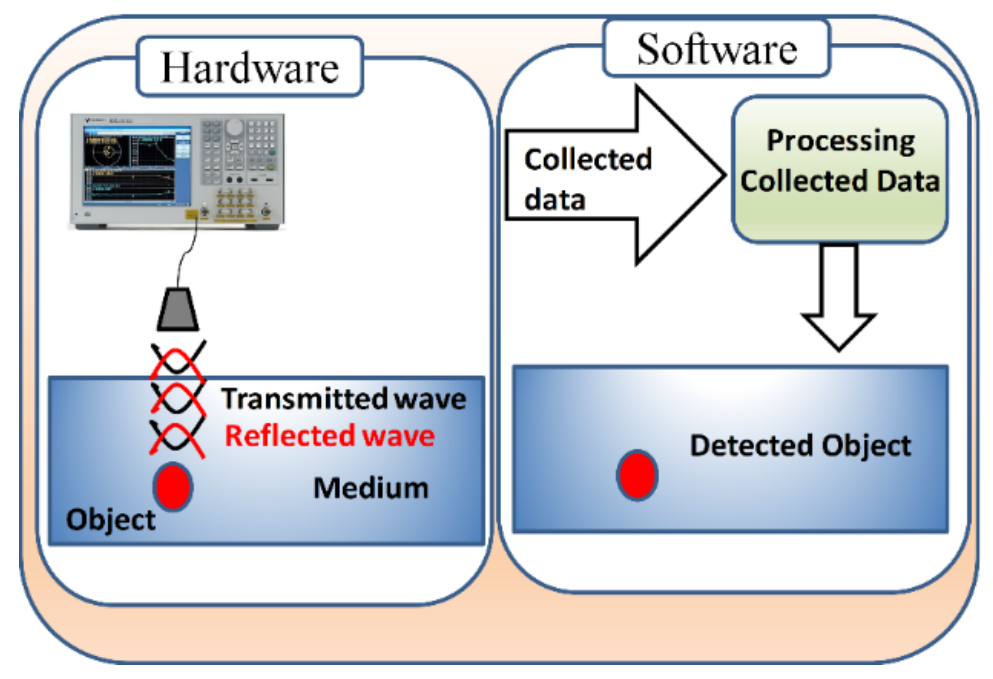

Figure 1. A schematic diagram showing the components of the microwave imaging (MI) system.

Knowledge of the dielectric properties of breast tissues is essential for the understanding of the interactions between the electromagnetic fields (i.e., microwaves) and the breast tissue. The dielectric properties of breast tissues are represented by a complex permittivity where the real part represents the ability of the material to store microwave energy, whereas the imaginary part, or the loss factor, indicates the ability of the material to absorb microwave energy [14]. Microwave-based detection modalities are mainly based on the observation of a high variation of the dielectric properties between normal and malignant breast tissues [12,13]. Microwaves reflected off or scattered from breast tissues are expected then to result in an image showing a contrast between malignant and healthy tissues.

Several research groups studied the dielectric properties of normal and malignant breast tissues in the microwave region. These studies established that the malignant breast tissues have significant differences in their dielectric properties in comparison to nearby healthy breast tissues. Table 2 gives a chronological summary of several published studies of the dielectric properties' contrast between normal and malignant human breast tissues [13,15-23]. The table is subdivided into five categories: the year of study, the author names, the operating frequency, the probe used in measurements, and the number of samples. The accuracy of the difference between the normal and tumourous tissues of each reported study is based on many factors such as the frequency range for the fitting model, tissue type and size, number of samples used for the study, sensing depth and volume, time from excision to measurement of tissues in the study, type of the fitting data model used, and the environment of testing (i.e., in vivo or ex vivo states) [19,20,24-27]. 
Table 2. Chronological summary of several studies of the dielectric properties of human female breast tissues.

\begin{tabular}{|c|c|c|c|c|c|}
\hline Year & Author & Frequency Range & Probe Type & Tissue Type & $\begin{array}{l}\text { No. of } \\
\text { Samples } \\
\text { (Patients) }\end{array}$ \\
\hline 1984 & Chaudhary et al. [13] & $3 \mathrm{MHz}-3 \mathrm{GHz}$ & $\begin{array}{l}\text { Open-ended } \\
\text { coaxial probe }\end{array}$ & $\begin{array}{l}\text { Normal (unspecified) } \\
\text { and malignant }\end{array}$ & 15 \\
\hline 1988 & Surowiec et al. [15] & $20 \mathrm{kHz}-100 \mathrm{MHz}$ & $\begin{array}{l}\text { End-of-the-line } \\
\text { capacitive probe }\end{array}$ & $\begin{array}{l}\text { Normal (various) } \\
\text { and malignant }\end{array}$ & 7 \\
\hline 1992 & $\begin{array}{l}\text { Campbell and } \\
\text { Land [16] }\end{array}$ & $3.2 \mathrm{GHz}$ & $\begin{array}{l}\text { Resonant } \\
\text { cavity probe }\end{array}$ & $\begin{array}{l}\text { Normal (various) and } \\
\text { benign, malignant }\end{array}$ & 37 \\
\hline 1994 & Joines et al. [17] & $50-900 \mathrm{MHz}$ & $\begin{array}{l}\text { Flat-ended } \\
\text { coaxial probe }\end{array}$ & $\begin{array}{l}\text { Normal (unspecified) and } \\
\text { malignant }\end{array}$ & 12 \\
\hline 2004 & Choi et al. [18] & $0.5-30 \mathrm{GHz}$ & $\begin{array}{l}\text { Open-ended } \\
\text { coaxial probe }\end{array}$ & $\begin{array}{l}\text { Lymph nodes and } \\
\text { malignant }\end{array}$ & 12 \\
\hline 2007 & Lazebnik et al. [19] & $0.5-20 \mathrm{GHz}$ & $\begin{array}{l}\text { Open-ended } \\
\text { coaxial probe }\end{array}$ & $\begin{array}{l}\text { Normal (adipose and } \\
\text { glandular) and malignant }\end{array}$ & 196 \\
\hline 2009 & Halter et al. [20] & $100 \mathrm{~Hz}-8.5 \mathrm{GHz}$ & $\begin{array}{l}\text { Electrical } \\
\text { impedance } \\
\text { spectroscopy probe }\end{array}$ & $\begin{array}{l}\text { Fibrocystic and adipose } \\
\text { and tumour tissues }\end{array}$ & 6 \\
\hline 2014 & Sugitani et al. [21] & $1-6 \mathrm{GHz}$ & $\begin{array}{l}\text { Open-ended } \\
\text { coaxial probe }\end{array}$ & $\begin{array}{l}\text { Fibroglandular and } \\
\text { tumour tissues }\end{array}$ & 102 \\
\hline 2015 & Martellosio et al. [22] & $0.5-50 \mathrm{GHz}$ & $\begin{array}{l}\text { Open-ended } \\
\text { coaxial probe }\end{array}$ & $\begin{array}{l}\text { Adipose and } \\
\text { tumour tissues }\end{array}$ & Unspecified \\
\hline 2017 & Martellosio et al. [23] & $0.5-50 \mathrm{GHz}$ & $\begin{array}{l}\text { Open-ended } \\
\text { coaxial probe }\end{array}$ & $\begin{array}{l}\text { Adipose and } \\
\text { tumour tissues }\end{array}$ & 220 \\
\hline 2018 & Cheng et al. [28] & $0.5-8 \mathrm{GHz}$ & $\begin{array}{l}\text { Open-ended } \\
\text { coaxial probe }\end{array}$ & $\begin{array}{l}\text { Normal (unspecified) } \\
\text { benign and tumour }\end{array}$ & 509 \\
\hline 2019 & Hussein et al. [29] & $\begin{array}{l}200 \mathrm{MHz} \text { to } \\
13.6 \mathrm{GHz}\end{array}$ & $\begin{array}{l}\text { Open-ended } \\
\text { coaxial probe }\end{array}$ & $\begin{array}{l}\text { Normal (unspecified) and } \\
\text { tumour tissues }\end{array}$ & 48 \\
\hline
\end{tabular}

Several studies have investigated the contrast between the dielectric properties of normal and malignant breast tissues [13,17]. The studies demonstrated by Chaudhary et al. 1984, Surowiec et al. 1988, and Joines et al. 1994 had some limitations for estimating the differences between the dielectric properties of normal and malignant breast tissues. The reasons for such limitations are the employment of a small number of samples (patients), the use of a small range of frequencies not exceeding $3.2 \mathrm{GHz}$, and ignoring the study of the dielectric properties' differences between the three types of normal, benign, and malignant breast tissues [19]. On the other hand, the study introduced by the University of Wisconsin and the University of Calgary reported the dielectric properties of normal, benign, and malignant breast tissues within an ultra-wideband frequency range. However, this study had some limitations as they roughly used a sample volume depth on the order of the magnitude. Further, they used a Cole-Cole model for data fitting to plot the data in a linear fashion, which instead should have been plotted in a logarithmic fashion. This can have a significant impact on the measured data, apart from the effects of sample temperatures, patients' age, and time taken between the measurements and excision of the samples [20,24,30]. The study reported in [20] introduced the differences in dielectric properties between in vivo and ex vivo states of breast tissues. However, this study considered a small sample of six women. The studies reported in $[21-23,28]$ used larger samples and a wide range of frequencies for measuring the differences between the dielectric properties of normal and tumourous tissues. In summary, in spite of the many published studies on the contrast of the dielectric properties between normal and tumourous breast tissues, many challenges still exist. These challenges include the inaccurate estimation of the in vivo contrast, uncertainties in measurement methods, and the results not being in agreement with other standard detection methods.

With the advancement of the nanotechnology field and nanomaterials, several studies [31-33] proposed and investigated the possibility of improving the available cancer detection methods 
(magnetic resonance imaging (MRI), magneto-acoustic tomography (MAT), computed tomography (CT), and near-infrared (NIR) imaging) by combining the detection method with magnetic nanoparticle materials that are biocompatible such as iron oxide nanoparticles. In microwave detection for breast cancer, some recent studies explored the advantages of using magnetic nanoparticles to improve the contrast between the dielectric properties of normal, benign, and malignant breast tissues, as well as the in vivo and ex vivo states of breast tissues [31-34].

\section{Microwave Imaging for Breast Cancer Detection}

Microwave-based detection techniques offer several advantages over other detection methods such as being inexpensive, non-invasive, non-ionizing, and a comfortable form of treatment [13,20]. In addition, MI techniques provide higher sensitivity and the ability to detect small breast tumours as these techniques are based on the contrast of electrical properties between normal and tumourous breast tissues [13,20]. Such detection techniques are based on the hypothesis that the electrical properties, namely the permittivity and conductivity of malignant breast tissues, differ from those of healthy breast tissues within the microwave band $[35,36]$. In literature, there are three modalities that have been explored for microwave-based breast detection. As seen in Figure 2, these methods can be categorized as passive, hybrid, and active methods [35-39].

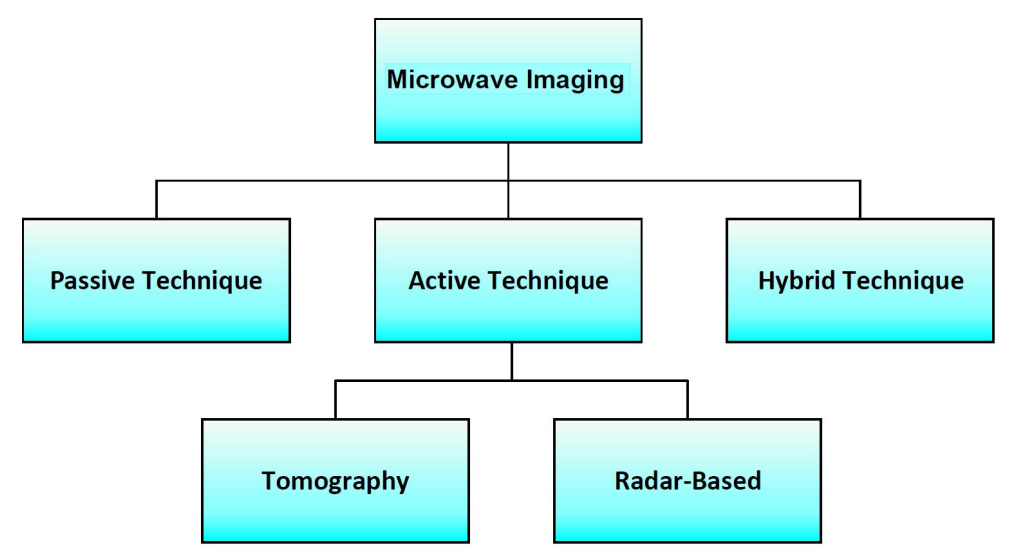

Figure 2. Block diagram showing the different modalities that have been explored for microwave-based breast cancer detection.

In the passive approach, a radiometry device is utilized to measure the differences in temperature between healthy and malignant breast tissues. Tumourous tissues exhibit a higher temperature compared to the surrounding normal tissues due to differences in electrical properties [38,39]. Hybrid techniques, termed thermoacoustic methods, employ microwave sensors and ultrasonic transducers to detect the presence of a tumour. In the hybrid techniques, the breast tissues are illuminated by microwaves, which are then absorbed by them. Malignant tissues significantly absorb more energy than normal tissues and radiate stronger acoustic waves due to their higher electrical conductivity than that of the surrounding normal tissues. An ultrasound transducer located close to the breast then measures the reflected acoustic signals, which are then processed to reconstruct an image $[40,41]$. Active MI employs microwave signals to illuminate the breast tissues. The variation in the dielectric properties between malignant and normal breast tissues is then measured within specific microwave frequency range [42]. Such a technique estimates the back-scattered signals from the breast tissues to reconstruct an image that indicates the presence of a tumour by virtue of stronger reflected signals than those of healthy tissues [42-44].

Techniques for breast cancer imaging using active microwave methods are extensive, including tomography and radar-based techniques [44,45]. The tomography approach is usually performed iteratively and can be represented by a nonlinear inverse problem that requires significant computational resources for producing the dielectric properties of the breast. Imaging of the breast 
tissues can be constructed from the recovered microwave data file through inverse scattering algorithms that estimate the constitutive parameters of the breast tissues by analysing the absorbed and reflected microwave signals [46,47]. The radar-based approaches utilize an external microwave source to illuminate the breast tissues with ultra-wideband (UWB) signals. The back-scattered signals from the breast are used for detecting breast tumours [48-50].

\subsection{Microwave Tomographic Imaging}

Microwave tomography (MT) applies microwave signals that illuminate the breast tissue to reconstruct the permittivity and conductivity of the breast. This approach aims at the complete reconstruction profile of the dielectric properties of the imaged object. It generally leads to an ill-posed nonlinear inverse scattering problem, which reconstructs the image by estimating the scattered fields and compares it with the signals obtained from a normal breast [46]. The MT method has been investigated in theoretical and experimental studies for breast cancer detection by several research groups [46,51-54]. MT uses three steps to reconstruct an image of the breast tumours: collecting microwave tomogram data, analysing the data, and finally, displaying the images $[47,55]$. The acquisition of the microwave data is performed by exposing the breast tissue to a microwave signal and then producing the microwave tomogram data file. The microwave tomogram data analysis is performed using inverse scattering algorithms that calculate the dielectric properties of the normal and tumourous breast tissues from the microwave tomogram data files. The data visualization part is achieved by utilizing 2D or 3D tomogram images that show the presence, location, and size of the tumour $[37,54]$. The MT system for breast cancer detection combines both a hardware part that includes microwave sensors and probes and a software part that includes image reconstruction approaches and algorithms.

Reconstruction methods are an essential part of MT to reconstruct an image of breast tumours. In the literature, there are two different methods that have been used for solving the nonlinear inverse MT problems for breast imaging, namely the gradient-based local and global methods [56-59]. In both techniques, the MT problem is formulated as a cost function, which is solved through an iterative process.

In the local gradient-based approach, the nonlinear inverse problems are solved by using several data-processing algorithms developed for breast cancer detection such as the conjugate gradient least squares (CGLS) algorithm, least squares QR (LSQR) algorithm, and Landweber algorithm [58-60]. The advantage of using the gradient-based algorithms is their low processing time due to the smaller number of iterations [37,61]. The global method is able to reach the global minimum of a cost function through randomization, which searches for several local minima in the entire solution space and is not limited to a search only in the gradient direction. The global methods are based on evolutionary algorithms such as the genetic algorithm (GA) and particle-swarm optimization (PSO) algorithm [37,61]. There are several image reconstruction algorithms that have been developed and used in microwave tomography imaging approaches to solve complex ill-posed nonlinear problems for breast cancer detection [60,62-66].

In this sub-section, some of the most famous tomography MI systems in the literature are reviewed. We consider some factors that have an impact on each system such as the operating frequency, the type of antenna used, the number of channel data acquisition systems, the array type, the scanning time of examination, the coupling medium, the number of clinical trials, the type of algorithms used for reconstructing a 2D or 3D tomogram image, and most importantly, the size of the smallest detected tumour. These features are especially essential for showcasing the performance, accuracy, complexity, and simplicity of each reviewed system.

The first clinical prototype for the near-field tomography MI system for breast cancer detection was reported in [44]. In this work, a 32 channel data acquisition subsystem was developed, which incorporated a heterodyning modulation scheme, a $200 \mathrm{kHz}$ A/D board, and a signal phase and amplitude extraction. The system consisted of a cylindrical array of a transceiving monopole antenna array (16 elements) in the 
300-1000 MHz frequency range and an HP85070B dielectric probe kit in conjunction with an HP 8753C network analyser [44]. All components and modules were consolidated into a single cart for the purpose of portability. The fixed synthetic array of antennas was placed on an examination table and connected. Saline was used as the coupling medium between the breast and the antenna array. The architecture required the patient to lie down flat on a bed while placing the breast into the MI bath under the bed, as shown in Figure 3 [44]. The microwave clinical exam was conducted upon five women, and the scan time sessions taken were between 10 and 15 min per breast. Figure $4 \mathrm{a}$,b shows the resultant images of the recovered $900 \mathrm{MHz}$ relative permittivity and conductivity images for both left and right breasts, respectively, of Patient 1.

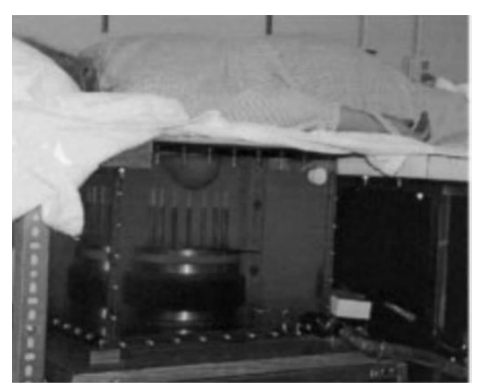

(a)

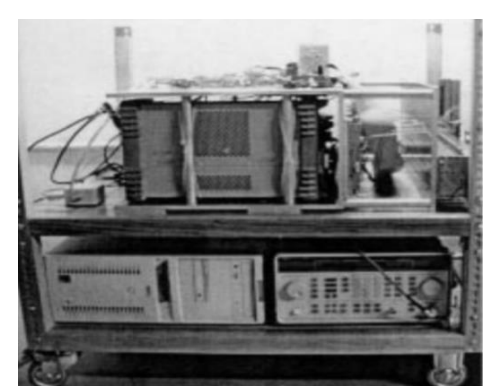

(b)

Figure 3. Prototype of the imaging system developed by Meaney et al. [44]. (a) View of the examination table. (b) View of the data acquisition system including the microwave source. Reprinted with permission from [44].

The same group also developed the first 3D prototype tomography MI system based on the 3D finite element modelling (FEM) method for microwave tomography [67]. The new developed system overcame some limitations in both the hardware and software aspects of the previous system. The system consisted of an array of 16 monopole antennas. Hydraulic seals in the tank base were designed to allow free vertical antenna motion over the full tank span, ensuring proper data acquisition from the chest wall to the nipple region for all breast sizes, as shown in Figure 5. The system was capable of measuring signals down to levels compatible with sub-centimetre image resolution, while keeping the exam time well under two minutes and the duration of the processing time less than $20 \mathrm{~min}$. The reported ultra-fast system had unique synergy between the hardware and software as both were optimized to achieve a near real-time imaging with no compromise in accuracy. The antennas were divided into two interleaved sets of eight antennas controlled by separate motors for their vertical positioning, as illustrated in Figure 5 . The results from clinical trials demonstrated that a tumour with a size of $1.5 \mathrm{~cm} \times 1.2 \mathrm{~cm} \times 1 \mathrm{~cm}$ was detected in the right breast of a 55-year-old patient, as shown in Figure 6 [67]. 
(a)

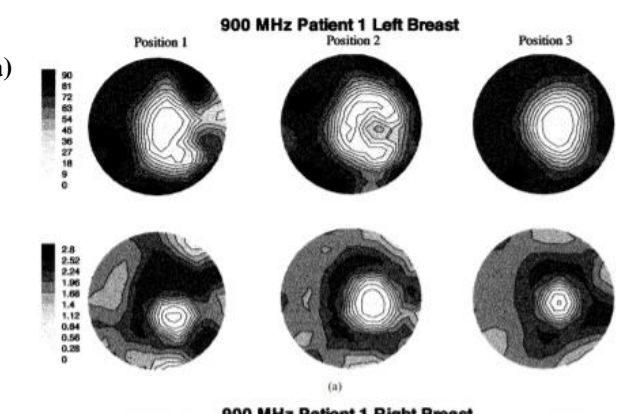

(b)
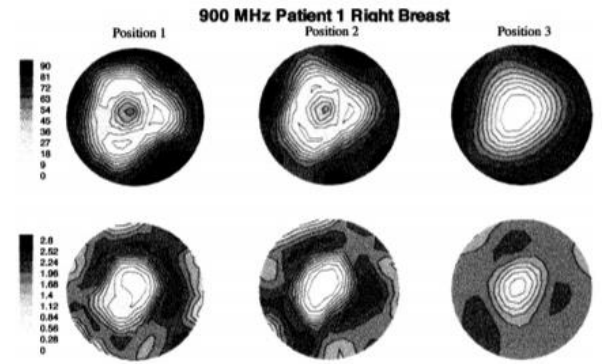

Figure 4. Recovered $900 \mathrm{MHz}$ relative permittivity and conductivity images from Patient 1: (a) left breast and (b) right breast. Reprinted with permission from [44].

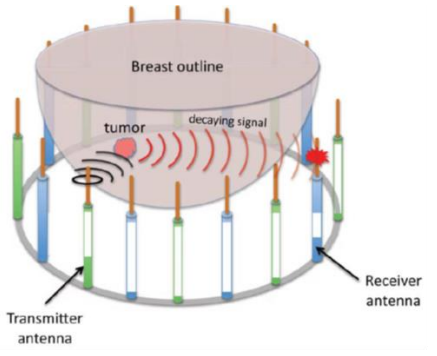

(a)

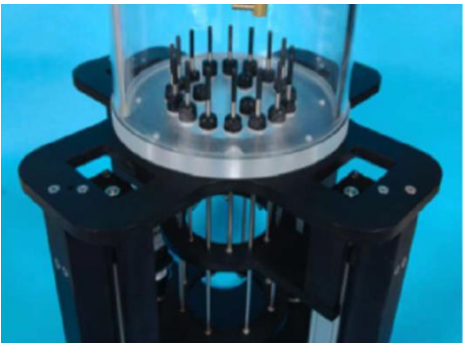

(b)

Figure 5. A prototype system for breast cancer testing developed by Grzegorczyk et al. [67]. (a) View of a 3D schematic representing the testing setup. (b) Photograph showing the system hardware. Reprinted with permission from [67].

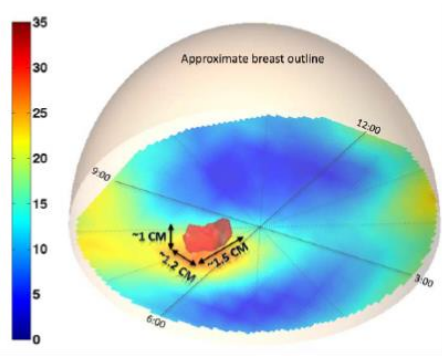

(a)

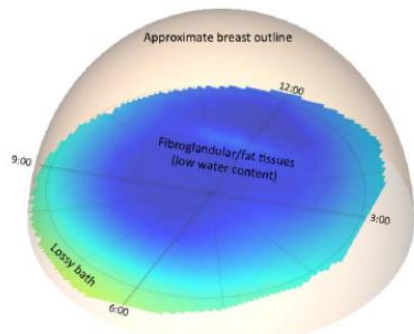

(b)

Figure 6. 3D microwave tomographic permittivity images at $1300 \mathrm{MHz}$ obtained from the system developed by Grzegorczyk et al. [67]. (a) The 3D structure of a tumour present in the right breast. (b) The 3D structure of a tumour-free left breast. Reprinted with permission from [67]. 
Son et al. developed a preclinical prototype MT system for breast cancer detection, as shown in Figure 7a [68]. In this system, a 16 element circular array was placed into an imaging bath having a matching liquid. Each antenna was used for signal transmission and reception over a frequency band ranging from $500 \mathrm{MHz}$ to $3000 \mathrm{MHz}$. A matching liquid was used to fill the MI bath to reduce reflections from the breast surface, as shown in Figure $7 \mathrm{~b}$. The total number of transmit-receive data points was 240 (measurements were performed for each frequency at each imaging plane). The data acquisition unit used a programmable switch matrix, as shown in Figure 8 [68].

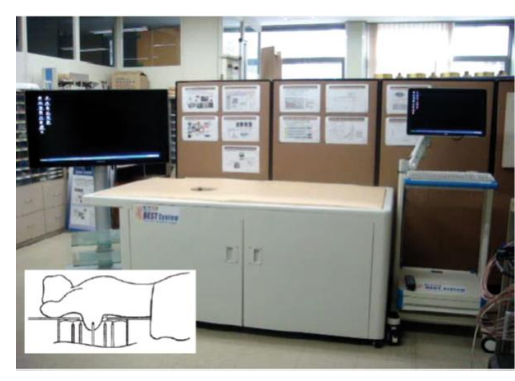

(a)

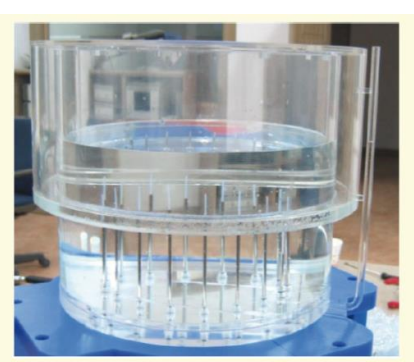

(b)

Figure 7. A prototype imaging system developed by Son et al. [68]. (a) View of the entire system. (b) View of the breast holder showing the antenna array in the liquid bath. Reprinted with permission from [68].

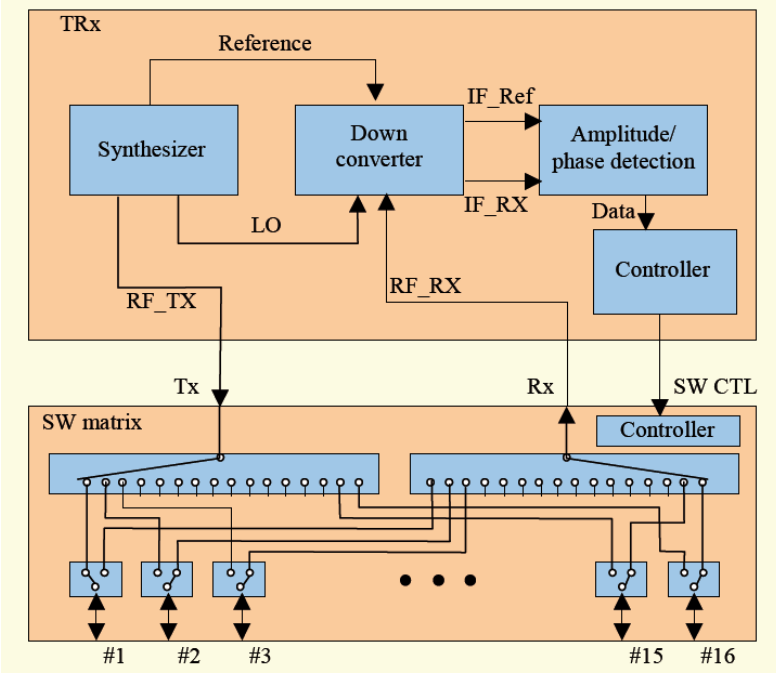

Figure 8. Schematic of the system developed by Son et al. [68]. Reprinted with permission from [68].

The proposed 2D tomography system in [68] is convenient for trials on patients and phantoms. The reported prototype system was used to detect a $10 \mathrm{~mm}$ tumour inside a phantom. Figure 9 shows the reconstructed images for the breast phantom with a cylindrical $10 \mathrm{~mm}$ tumour at $1700 \mathrm{MHz}$. Figure 9 shows the image of a breast phantom without a tumour, with a tumour positioned at the centre of the breast, and with a tumour positioned $30.0 \mathrm{~mm}$ right of the centre.

Pagliari et al. [69] developed the first prototype for a tomography MI system based on low-cost off-the-shelf microwave components, custom-made antennas, and a small form-factor processing system with an embedded field-programmable gate array (FPGA) for accelerating the execution of the imaging algorithm (see Figure 10). This prototype system was fast, accurate, and relatively low in price mainly because it was configured by an FPGA that was capable of executing the imaging algorithm 20 times faster than a multi-core CPU. Furthermore, this prototype system [69] was capable of detecting 
a tumour with an accuracy similar to the one that could be achieved using expensive equipment such as a vector network analyser (VNA). For image construction, a linear inversion method (I-MUSIC) was used instead of a non-linear inversion algorithm. The system operated over a relatively small bandwidth of $200 \mathrm{MHz}$ between 1.4 and $1.6 \mathrm{GHz}$ (see Figure 11). The relatively low cost for this system was maintained due to the availability of low-cost off-the-shelf components in the working frequency range of the system. Figure 12 depicts that a $40 \%-60 \%$ glycerine and water mixture was used to fill a $20 \mathrm{~mm}$ diameter plastic dielectric cylinder tank, which was intended to mimic the dielectric properties of a 2D breast phantom. A $12 \mathrm{~mm}$ diameter metallic cylinder was intended to mimic a tumour (see Figure 12). Figure 13 shows that the experimental results demonstrating the successful detection of a tumour having a size of $12 \mathrm{~mm}$ in diameter [69].

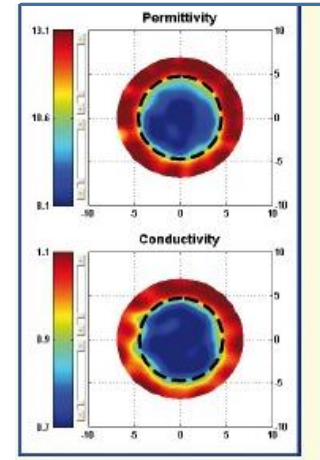

(a)

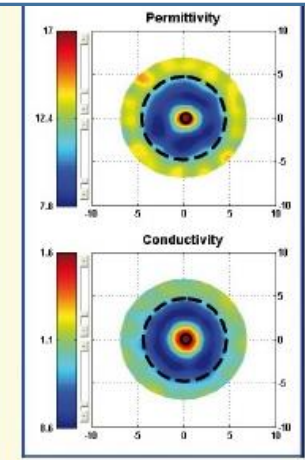

(b)

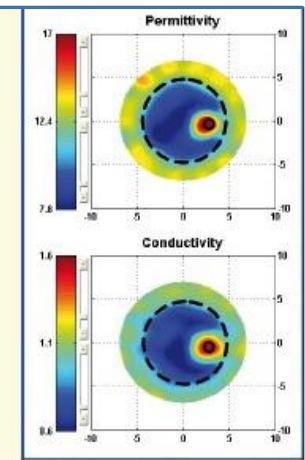

(c)

Figure 9. Reconstructed images at $1700 \mathrm{MHz}$ for a breast phantom with a cylindrical $10 \mathrm{~mm}$ tumour. (a) Image of the breast without a tumour. (b) Image of the breast with a tumour positioned at the centre of the breast. (c) Image of the breast with a tumour positioned $30 \mathrm{~mm}$ right of centre. Marked big circles show the boundaries of the breast [68].

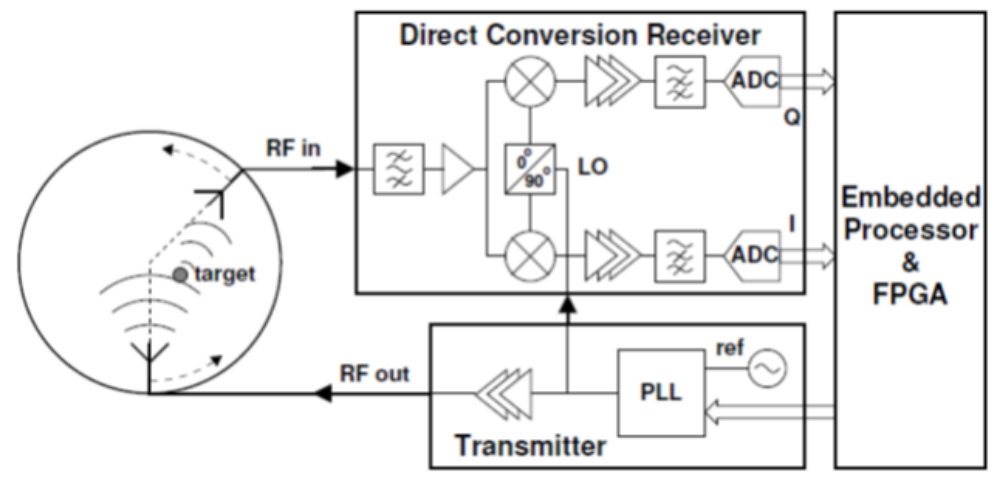

Figure 10. A schematic of the system developed by Pagliari et al. [69]. Reprinted with permission from [69].

Jeon et al. introduced a clinical trial prototype MT system for detecting breast tumours in [70]. This clinical trial prototype system was designed to work in the range of 3 to $6 \mathrm{GHz}$ with a fast forward solver (FFS) algorithm. Figure 14 shows this MT clinical trial system at a hospital in Seoul. The clinical trial prototype system was used for investigating 15 women ranging in age from 40 to 68 years [70]. Clinical trial results illustrated that a tumour with a size of $25 \mathrm{~mm}$ could be detected in the left breast (see Figure 15) [70]. 


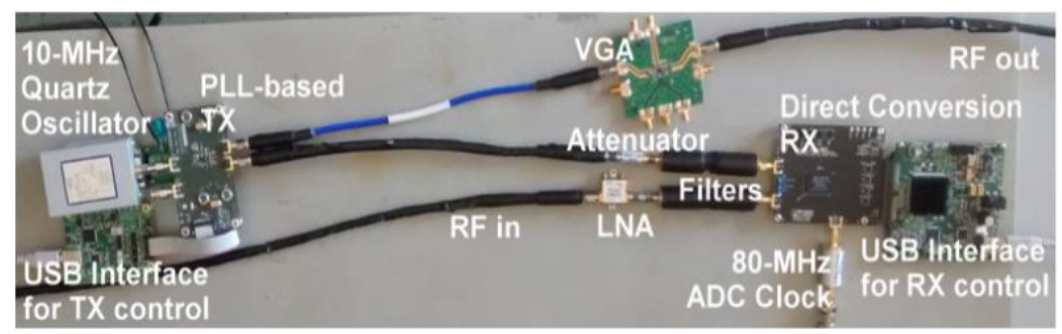

Figure 11. Photograph of the circuit used in the system developed by Pagliari et al. [69]. Reprinted with permission from [69]. LNA, low noise amplifier.

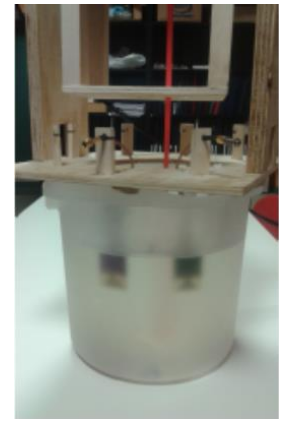

(a)

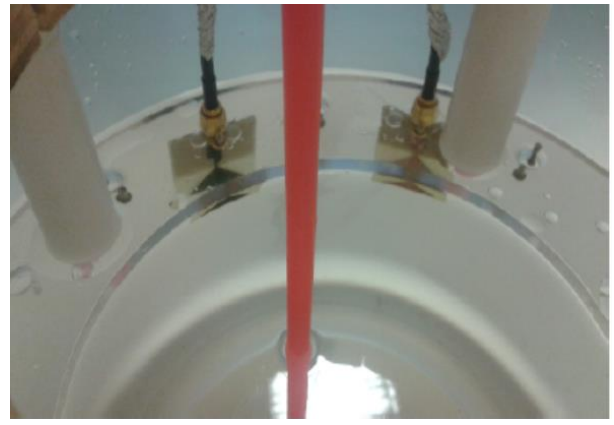

(b)

Figure 12. Photograph of a breast cancer detection system developed by Pagliari et al. [69]. (a) View of the antennas' setup showing the breast holder consisting of a tank filled with a glycerine-water mixture. (b) Photograph of a vertically aligned cylinder representing the detection target. Reprinted with permission from [69].

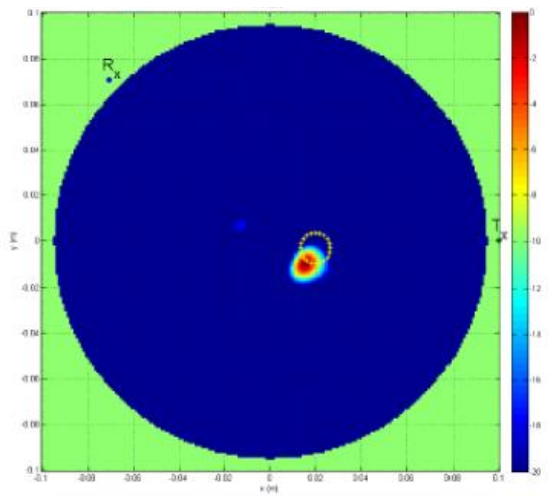

(a)

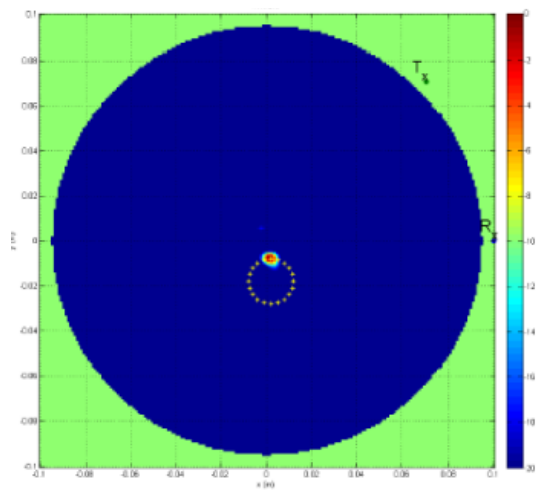

(b)

Figure 13. Reconstructed MT images obtained using the system developed by Pagliari et al. [69]. (a) A $12 \mathrm{~mm}$ tumour is indicated by the red spot inside a metallic cylinder breast phantom. (b) A $12 \mathrm{~mm}$ tumour is indicated by the red spot inside a dielectric cylinder breast phantom. Reprinted with permission from [69]. 


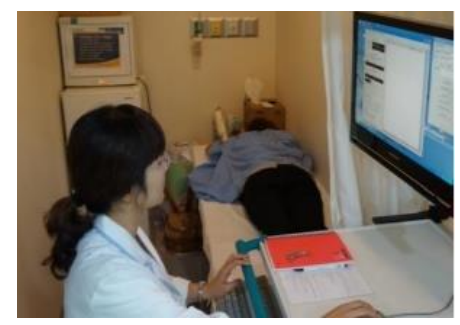

Figure 14. Clinical trial view of an MT test system developed by Jeon et al. [70]. Reprinted with permission from [70].

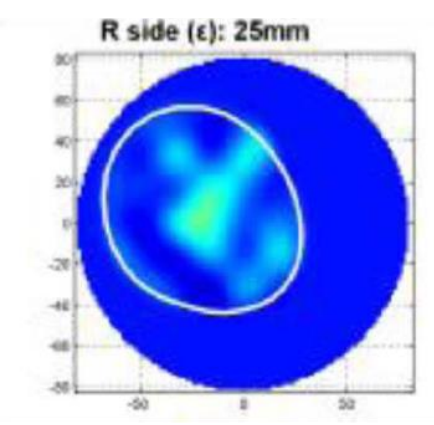

(a)

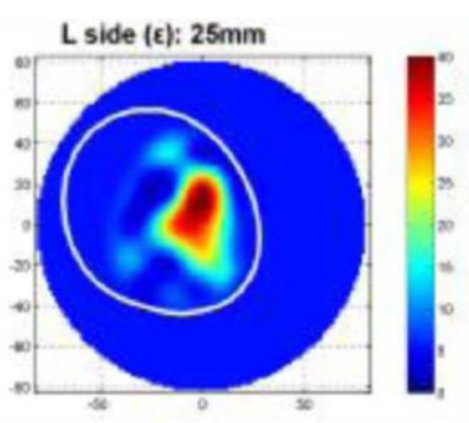

(b)

Figure 15. Reconstructed MT images obtained using the system developed by Jeon et al. [70]. (a) An image of the right tumour-free breast. (b) An image of the left breast, which indicates the presence of a $25 \mathrm{~mm}$ tumour. Reprinted with permission from [70].

\subsection{Radar-Based Microwave Imaging}

Radar-based techniques employ an external microwave source to illuminate breast tissue with ultra-wideband (UWB) signals. Back-dispersed signals from the breast are used to detect breast tumours. Bridges et al. proposed the first radar-based MI system in 1997 [71]. It avoids using nonlinear inverse scattering algorithms for recovering the complete profile of the breast's dielectric properties to construct an image of the breast [72,73]. Bridges' method utilized an ultra-wide microwave signal to illuminate the breast tissues using an antenna array placed at different locations surrounding the breast $[73,74]$. The back-scattered microwave signals were then received by the same antennas and processed by radar-based MI methods to detect the tumour's location and size. These back-scattered signals indicated the presence of the tumour because of the contrast in the dielectric properties between the normal and tumourous tissue at microwave frequencies. Radar-based MI techniques involve radar-based MI methods and radar-based MI beam-forming algorithms [75]. Radar-based MI methods are based on different radar configurations that employ elements of an antenna array that transmit or receive (separately or simultaneously) microwave signals into or from the breast. The beam-forming algorithms are used to reconstruct images from the reflected signals.

Radar-based MI techniques can be classified into five approaches: confocal microwave (CM), tissue sensing adaptive radar (TSAR), MI via space-time (MIST), multi-static adaptive (MSA), and timedomain data adaptive (TDDA). The beam-forming algorithms can be grouped into several imaging algorithms for breast tumour detection including delay and sum logarithm (DAS), time reversal (TR) algorithms, artefact removal algorithms (AR), time-of-arrival algorithm (TOA), skin subtraction algorithm (SSA), inverse scattering algorithm (ISA), Gauss-Newton iterative algorithm (GNIA), matched-filtering algorithm (MFA), generalized likelihood ratio test (GLRT), constrained robust capon algorithm (CRC), inverse fast Fourier transform algorithm (IFFT), local discriminant basis (LDB), forward-backward time-stepping (FBTS), time-shift-and-add algorithm (TSAA), linear constraint 
minimum variance (LCMV), genetic algorithm (GA), filtered delay-and-sum (FDAS), skin reflection removal (SRR), double constrained robust Capon beamforming (DCRCB), norm constrained Capon beamforming (NCCB), empirical mode decomposition (EMD), modified delay-and-sum (MDAS), delay-multiply-and-sum (DMAS), and robust and artefact resistant (RAR).

This section reviews these methods and algorithms that were specifically used for breast cancer detection. We summarize and tabulate these methods and algorithms in Table A1 in Appendix A. These tables classify the methods and algorithms into seven categories: the year of the study, the author names, the operating frequency, the number of antennas employed, the tumour size, the radar-based MI techniques, and the image reconstruction algorithms.

Klemm et al. designed and implemented a UWB frequency-domain radar-based MI system [76]. The system consisted of an aperture array of UWB antennas that were positioned on a section of the hemisphere that conformed to the curved breast shape, as shown in Figure 16a. The UWB array was positioned with the breast comfortably resting on the spherical shell, as shown in Figure 16b. The signals were captured by a data acquisition module and transferred to a computer [76]. Clinical imaging results showed that the system could detect an $8 \mathrm{~mm}$ tumour, as shown in Figure 17.

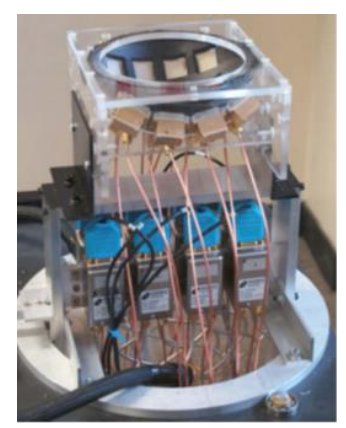

(a)

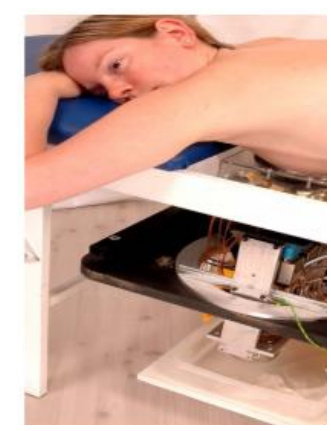

(b)

Figure 16. Prototype UWB frequency-domain radar-based MI system developed by Klemm et al. [76]. (a) View of the breast holder consisting of a conformal MI array, feed, and a switching system. (b) A photo of the prototype system setup for breast cancer detection showing a healthy female volunteer lying in a prone position. Reprinted with permission from [76].

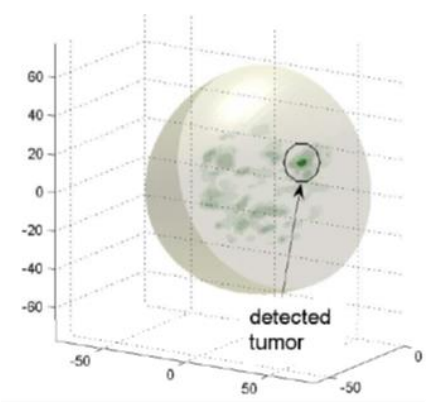

(a)

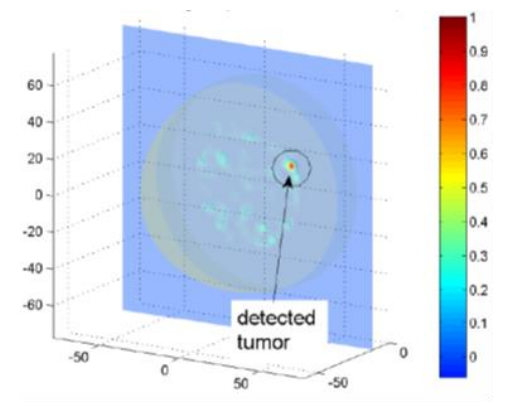

(b)

Figure 17. Clinical imaging results using a radar-based UWB microwave system developed by Klemm et al. [76]. (a) A 3D image. (b) A 2D image showing the presence of a tumour. Reprinted with permission from [76].

Zhurbenko et al. reported a radar-based frequency-domain system [77]. The architecture of the system consisted of 32 monopole antennas, a measurement unit, a data acquisition system, 
and a computer. The antennas were used to measure the amplitude and phase of the scattered fields in the 3D imaging domain using electronic scanning in the frequency range from 0.3 to $3 \mathrm{GHz}$ [77]. Fear et al. developed a 3D UWB tissue sensing adaptive radar (TSAR) MI prototype system for breast cancer detection [78]. This system consisted of a patient interface employing a padded table with a hole through which the breast dropped into a cylindrical container, as shown in Figures 18 and 19. The mono-static approach was used to collect data, and a filtering circuit was used to reduce reflections from the skin tissues. The system was tested on eight volunteers ranging in age from 32 to 47 years [78]. The system was able to detect breast tumours of $5 \mathrm{~mm}$ in diameter, as depicted in Figure 20.

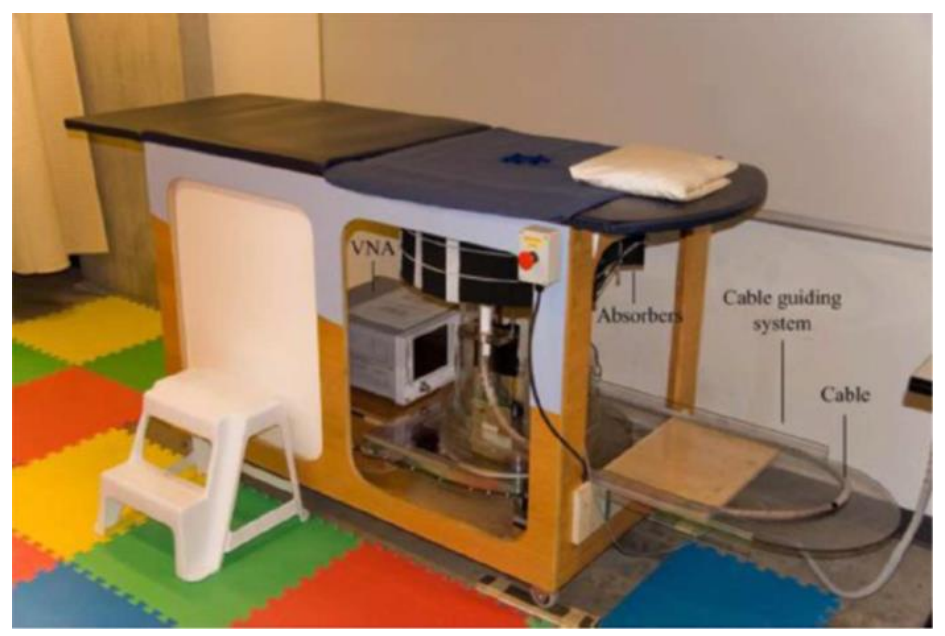

Figure 18. Tissue sensing adaptive radar (TSAR) prototype radar-based MI system for breast cancer detection developed by Fear et al. [78]. Reprinted with permission from [78].

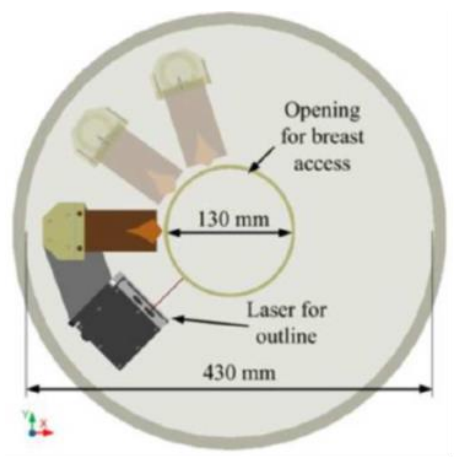

(a)

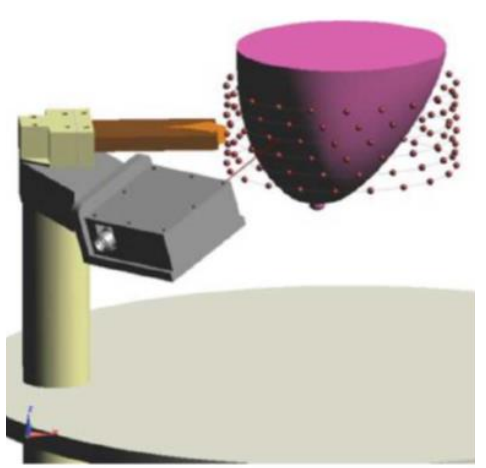

(b)

Figure 19. View of the radar-based MI system for breast cancer detection developed by Fear et al. [78]. (a) Top-down view of the antennas and laser setup. (b) Showing the breast holder consisting of a tank, laser, and antennas. Reprinted with permission from [78].

Kikkawa et al. developed a radar-based time-domain MI system using impulse radio ultra-wideband complementary metal oxide semiconductor (IR-UWB-CMOS) integrated circuits [79]. The CMOS circuits consisted of a transmitter circuit, an UWB low noise amplifier (LNA), an equivalent time sampling circuit, a Gaussian mono-cycle pulse (GMP) generator, and an analogue-to-digital converter. The UWB antennas were used to transmit digitally generated GMP signals. A confocal imaging algorithm was used to transform the received signals to pixels, as shown in Figure 21 [79]. 

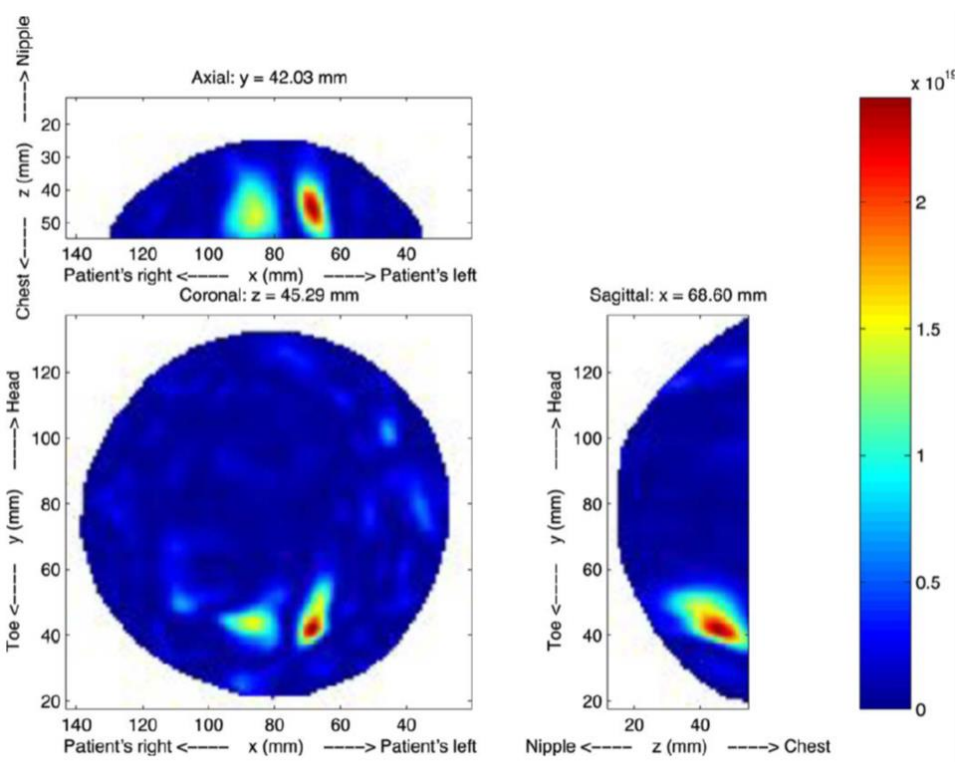

Figure 20. Reconstructed TSAR images using the system developed by Fear et al. [78]. Reprinted with permission from [78].

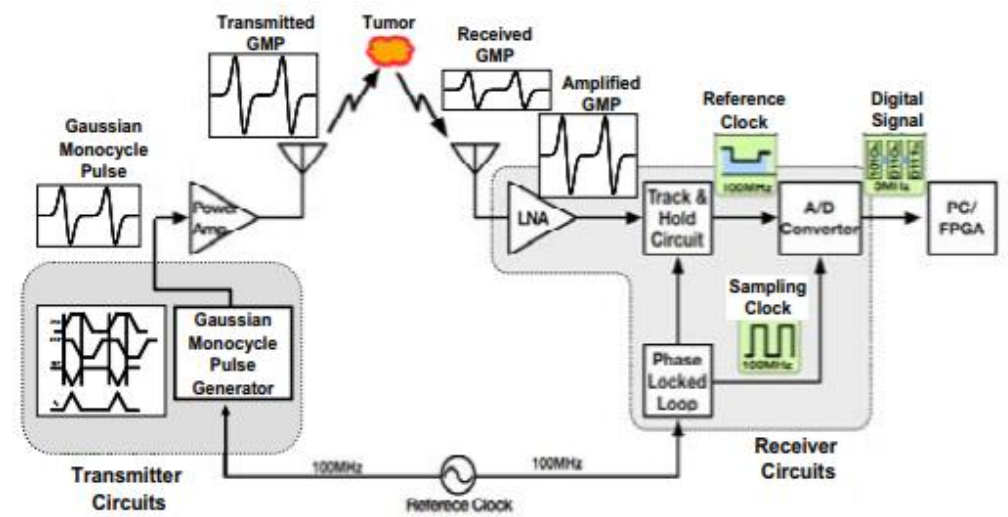

Figure 21. CMOS-based breast cancer detection system developed by Kikkawa et al. [79] consisting of transmitter and receiver circuits. The transmitter circuits contain a Gaussian mono-cycle pulse (GMP) generator, a power amplifier, and UWB antennas. The receiver circuits consist of a GMP receiver front-end low-noise amplifier (LNA) and a GMP data acquisition unit. Reprinted with permission from [79].

Porter et al. introduced an experimental multi-static radar-based time-domain MI system for breast cancer detection, as shown in Figure 22 [80]. The system consisted of a radome, which was the interface between the system and the breast that was positioned inside it, a 16 element antenna array, a commercial pulse generator, an oscilloscope, a switch matrix, and a computer (see Figure 23). The system used time-domain measurements. A proof-of-concept was demonstrated by imaging breast tumours in realistically-shaped breast phantoms. The system detected a spherical tumour with a radius of less than $1 \mathrm{~cm}$ inserted in a realistically-shaped breast phantom, as shown in Figure 24 [80]. 

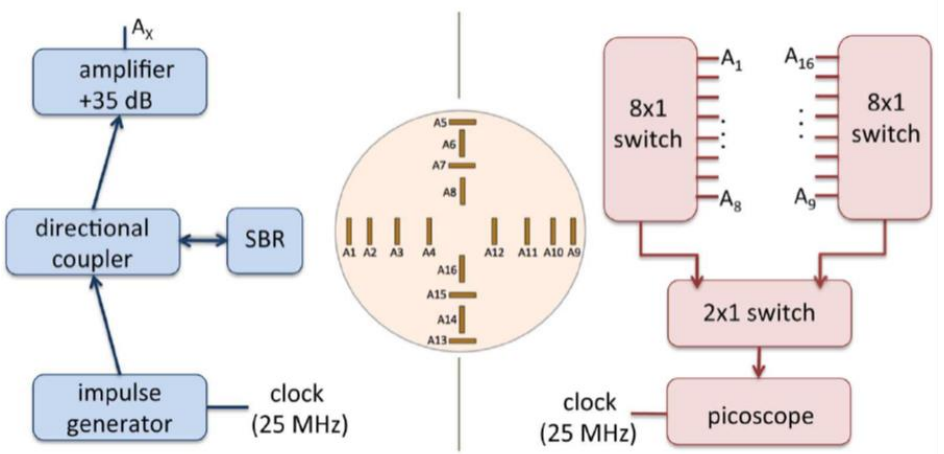

Figure 22. A schematic diagram representing the system developed by Porter et al. [80]. Reprinted with permission from [80].

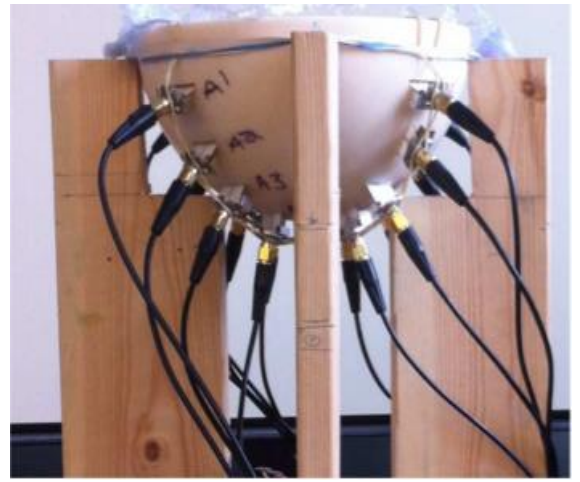

Figure 23. A breast cancer detection system using an antenna array with radome, developed by Porter et al. [80]. Reprinted with permission from [80].

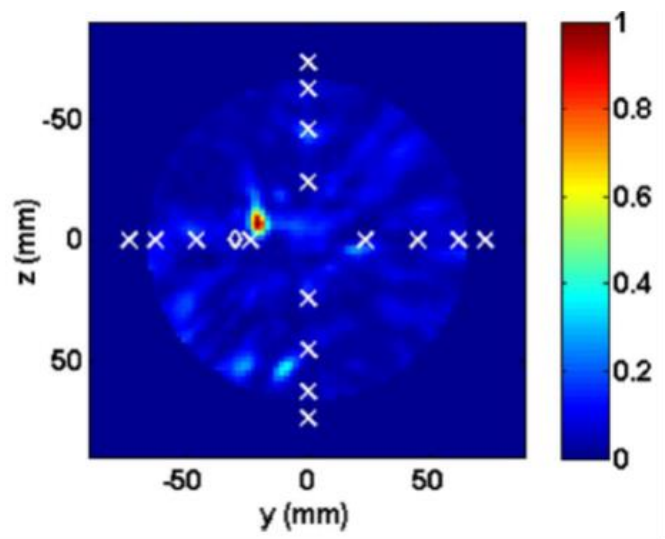

Figure 24. Reconstructed image of a breast phantom detection system developed by Porter et al. [80]. The tumour is indicated by the red spot; the $\mathrm{x}$ markers represent the positions of the antennas; and the diamond markers represent the actual location of the tumour centres. Reprinted with permission from [80].

Kwon et al. proposed a complementary metal-oxide semiconductor (CMOS) time-domain MI system for breast cancer imaging [81]. The proposed MI system consisted of 16 UWB transceivers that surrounded a 3D hemispherical phantom and a master controller for data collection. The data were processed using the multi-static delay and sum (DAS) algorithm to reconstruct an image of a $3 \mathrm{~mm}$ tumour inserted inside a 3D hemispherical breast phantom model [81]. Santorelli et al. designed and implemented a 3D radar-based time-domain MI system [82]. The system was compact, cost-effective, 
and wearable. The system consisted of a flexible circuit with 16 UWB embedded antennas, two micro-controllers, a shaping circuitry, a recording oscilloscope, an impulse generator, and a $16 \times 2$ switching matrix network implemented using solid-state technology (see Figure 25). The switching matrix allowed the antennas to operate independently as either transmitters or receivers. The system performance was clinically tested showcasing its capability for detecting a $1 \mathrm{~cm}$ tumour inserted inside a breast phantom (see Figure 26) [82].

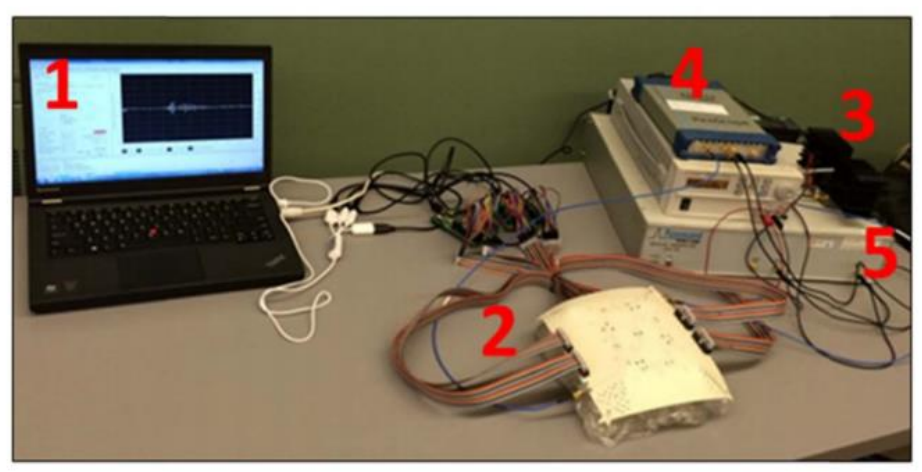

Figure 25. Microwave time-domain system for breast cancer imaging developed by Santorelli et al. [82]. The system components indicated on the photograph are (1) a laptop for transmitting control bits and saving the recorded data, (2) a flexible circuit board containing 16 antennas, the switching matrix, and the two micro-controllers, (3) the pulse shaping circuitry, (4) an oscilloscope, and (5) the impulse generator. Reprinted with permission from [82].

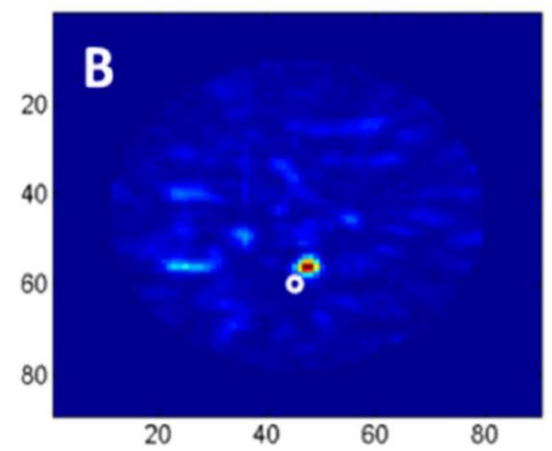

Figure 26. Reconstructed images of a rubber breast phantom obtained using the system developed by Santorelli et al. [82]. Reprinted with permission from [82].

Porter et al. developed a clinical prototype of a wearable radar-based time-domain MI system with a wearable patient interface for microwave breast tumour detection [83]. The wearable system consisted of 16 flexible monopole antennas distributed asymmetrically around a bra surface. The developed system had two good features compared with other systems including portability and compactness as the system did not require an examination table. The antennas did not have direct contact with the skin, which in turn eliminated the need for an immersion medium. Additionally, due to the close fit with the fabric that hosted the antenna array, the position of the breast relative to the array was known, which eliminated errors in the images arising from using the immersion liquid. A schematic of the system measurement setup is provided in Figure 27a, where a pulse is generated and amplified then fed into a switching network, which selects the transmitting and receiving antennas. The received signal was recorded by a picoscope. The wearable prototype was used for clinical testing on a healthy volunteer over a 28 day period. The results showed that the quality of reconstructed breast images was improved (see Figure 28) [83]. 


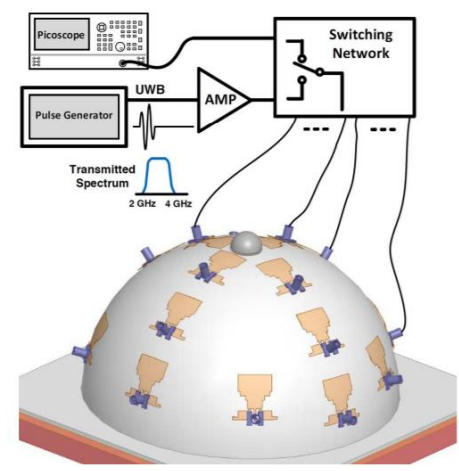

(a)

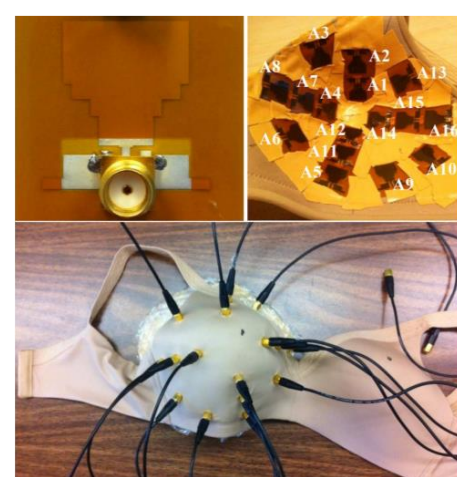

(b)

Figure 27. Microwave radar system for breast cancer detection developed by Porter et al. [83]. (a) A schematic of the microwave radar system setup. (b) A photograph showing the wearable prototype system. The top left photograph shows the connectorised monopole antenna. The top right photograph shows the antenna array inside the bra-cup with antennas' numbers marked. The bottom photograph shows the outside of the bra and the cables that connect to the antennas. Reprinted with permission from [83].

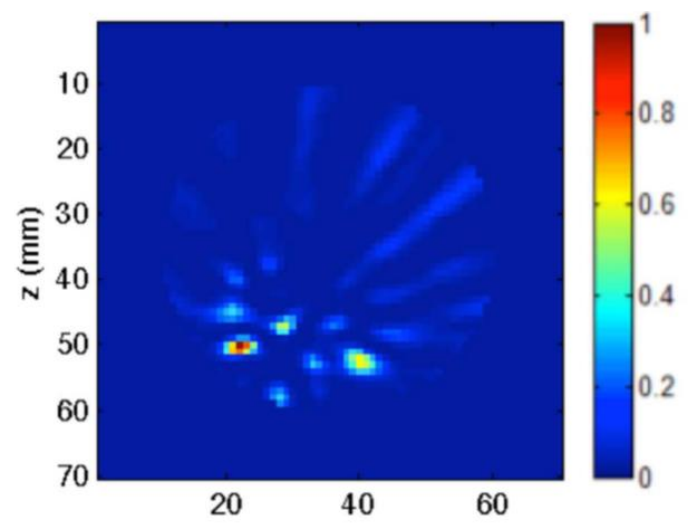

Figure 28. Reconstructed images for a breast slice taken at a depth of $6 \mathrm{~mm}$ from the chest wall obtained using the system developed by Porter et al. [83]. Reprinted with permission from [83].

Li et al. presented a cost-sensitive ensemble classification technique for microwave breast tumour detection [84]. They used two different sets of data for the classifications, one based on clinical experiments, which were collected every month in a clinical trial from 12 healthy volunteers over an eight-month period, and the other was based on heterogeneous breast phantoms. Simulated tumour responses were artificially added to existing data scans of healthy volunteers in order to assess the efficacy of the proposed classification techniques. The system consisted of 16 element antenna sensors to gather the illuminated and reflected signals from the breast tissues. The classification techniques were based on three fusion strategies to perform classification using cost-sensitive support vector machines. The presented classification techniques had the ability to distinguish between normal and malignant breast tissues [84]. A summary of some clinical radar-based MI studies is shown in Table 3. This table compares various clinical studies in terms of seven aspects: the scan time, maximum number of patients, the coupling medium, the examination table, the antenna array type, the acquisition and imaging, and the position.

Some other studies as shown in Table A2 focussed on the algorithms and methodologies employed for breast cancer detection, rather than on the hardware apparatus. This table summarizes the most recent innovative and effective methodologies for breast cancer imaging [85-101]. Those methodologies aimed at achieving multi-resolution images. Furthermore, some of these methodologies adopted magnetic nanoparticles $[87,88]$ and compressive sensing tools [97] to enhance the detection process, 
by exploiting linear approximations of the inverse scattering problem or iteratively solving a set of linear problems [99-101].

Table 3. Summary of some clinical MI studies.

\begin{tabular}{|c|c|c|c|c|c|c|c|}
\hline $\begin{array}{l}\text { Research } \\
\text { Group }\end{array}$ & $\begin{array}{l}\text { Scan } \\
\text { Time }\end{array}$ & $\begin{array}{l}\text { Max No. } \\
\text { of Patients }\end{array}$ & $\begin{array}{l}\text { Coupling } \\
\text { Medium }\end{array}$ & $\begin{array}{l}\text { Examination } \\
\text { Table }\end{array}$ & $\begin{array}{l}\text { Antenna } \\
\text { Array Type }\end{array}$ & $\begin{array}{l}\text { Acquisition } \\
\text { and Imaging }\end{array}$ & Position \\
\hline $\begin{array}{l}\text { Dartmouth College } \\
{[44,102-106]}\end{array}$ & $5 \mathrm{~min}$ & 175 & $\begin{array}{l}\checkmark \\
\text { medium }\end{array}$ & $\checkmark$ & $\begin{array}{l}\text { Monopole } \\
\text { synthetic }\end{array}$ & $\begin{array}{l}\text { Frequency, } \\
\text { tomography }\end{array}$ & Prone \\
\hline $\begin{array}{l}\text { University of Calgary } \\
{[78,107-109]}\end{array}$ & $30 \mathrm{~min}$ & 8 & $\begin{array}{l}\checkmark \\
\text { medium }\end{array}$ & $\checkmark$ & $\begin{array}{l}\text { Vivaldi } \\
\text { synthetic }\end{array}$ & $\begin{array}{l}\text { Frequency, } \\
\text { DAS }\end{array}$ & Prone \\
\hline $\begin{array}{l}\text { McGill University } \\
\text { [110] }\end{array}$ & $5 \mathrm{~min}$ & 13 & $\begin{array}{l}\checkmark \\
\text { shell }\end{array}$ & $x$ & $\begin{array}{l}\text { Microstrip } \\
\text { stationary }\end{array}$ & Time, DAS & Seated \\
\hline $\begin{array}{l}\text { Bristol University } \\
\text { [111-114] }\end{array}$ & $10 \mathrm{~S}$ & 267 & $\begin{array}{l}\checkmark \\
\text { shell }\end{array}$ & $\checkmark$ & $\begin{array}{l}\text { Slot } \\
\text { Hardware }\end{array}$ & $\begin{array}{l}\text { Frequency, } \\
\text { IDAS }\end{array}$ & Prone \\
\hline $\begin{array}{l}\text { Shizuoka University } \\
{[115,116]}\end{array}$ & $3 \mathrm{~min}$ & 2 & $\begin{array}{l}\checkmark \\
\text { shell }\end{array}$ & $\checkmark$ & $\begin{array}{l}\text { Stacked } \\
\text { patch } \\
\text { hardware }\end{array}$ & $\begin{array}{l}\text { Frequency, } \\
\text { DAS }\end{array}$ & Prone \\
\hline $\begin{array}{l}\text { Southern University } \\
\text { of } \\
\text { Science and } \\
\text { Technology [117] }\end{array}$ & $4 \mathrm{~min}$ & 11 & $\begin{array}{l}\checkmark \\
\text { medium }\end{array}$ & $\checkmark$ & $\begin{array}{l}\text { Horn } \\
\text { synthetic }\end{array}$ & $\begin{array}{l}\text { Frequency, } \\
\text { DAS }\end{array}$ & Prone \\
\hline $\begin{array}{l}\text { Hiroshima University } \\
\text { [118] }\end{array}$ & $5 \mathrm{~min}$ & 14 & $\begin{array}{l}\checkmark \\
\text { shell }\end{array}$ & $x$ & $\begin{array}{l}\text { Planar slot } \\
\text { synthetic }\end{array}$ & Time, DAS & Supine \\
\hline $\begin{array}{l}\text { London South Bank } \\
\text { University } \\
\text { [119] }\end{array}$ & $5 \mathrm{~min}$ & 45 & $\begin{array}{l}\checkmark \\
\text { shell }\end{array}$ & $\checkmark$ & $\begin{array}{l}\text { Planar } \\
\text { antenna } \\
\text { synthetic }\end{array}$ & $\begin{array}{l}\text { Frequency, } \\
\text { neural } \\
\text { network }\end{array}$ & Prone \\
\hline
\end{tabular}

\section{Conclusions}

Breast cancer remains the second-leading cause of death among women worldwide. Microwave imaging, which is noninvasive, non-ionizing, inexpensive, and harmless to humans, offers a promising alternative technique for breast tumour detection and for breast imaging. Over the past 30 years, significant progress has been made towards producing microwave imaging techniques for breast cancer detection. This paper presented an exhaustive summary of research in microwaves as it relates to breast cancer imaging and detection. Specifically, the review showed several aspects of the imaging modalities including imaging algorithms, imaging methods, sensors used, and the use of artificial intelligence. All the studies conducted so far gave a strong indication that microwave imaging has a high potential for both imaging of the human female breast and cancer detection. However, research showed that some significant challenges have been reported regarding practical implementations. The most important of these challenges faced were the need for high sensitivity sensors and insufficient image resolution.

Additionally, most commonly developed systems exhibited several other challenges and limitations that included: using multiple antennas with multiple feeds that led to a complex system, using a matching liquid between the antenna and the skin that led to a low signal-to-noise ratio (SNR) and a decrease in the performance of the system, using complex computations for reconstructing an image of the breast tissues and complex coding for image processing, low resolution and accuracy arising from the mutual coupling between multiple antennas, and high cost because of the use of multiple antennas with multiple feeds that required expensive equipment such as oscilloscopes, signal generators, and VNAs. 
Despite numerous studies and significant funding specifically related to the use of microwaves for breast cancer detection, and after more than 30 years of active research on the subject, a commercial and cost-effective microwave-based system is still not available. It is difficult to provide a satisfying answer to this crucial question. Nonetheless, it is perhaps timely to revisit the fundamental modalities that have been employed, mainly the fundamentals behind breast image reconstruction, which are based on the mathematically ill-posed inverse problem and radar-based techniques. Both techniques were initially developed for completely different applications, but have been proposed and adopted for breast imaging. Additionally, both techniques were developed for much simpler engineering problems unlike the problem of imaging highly complex and highly dispersive human tissues or the detection of anomalies within such tissues. In fact, both techniques are fundamentally centred on far-field assumptions. It is hoped that these conclusions will encourage a healthy debate on why a commercial cost-effective microwave-based detection system has yet to be made available despite almost 30 years of intensive research.

Author Contributions: Author Contributions: The individual contributions of the authors can be summarized in this paragraph. conceptualization, M.A.A., T.S.A. and O.M.R.; data collecting, M.A.A., T.S.A., and K.A.; writing-original draft preparation, M.A.A. and T.S.A.; writing-review and editing, M.A.A., H.A., and S.M.B.; visualization, M.A.A. and H.A.; final proof revision and preparation, H.A. and S.M.B.; supervision, O.M.R.; project administration, O.M.R. All authors have read and agreed to the published version of the manuscript.

Funding: This research was funded by King Fahd University of Petroleum and Minerals (KFUPM) under project number SB181027.

Acknowledgments: The authors acknowledge the support from King Fahd University of Petroleum and Minerals (KFUPM) through Project No. SB181027. The authors would like to thank Raziuddin Ahmed, Department of Mechanical Engineering, KFUPM, for his help in proofreading this manuscript.

Conflicts of Interest: The authors declare no conflict of interest.

\section{Appendix A}

Table A1. Chronological summary of MI radar-based methods and algorithms.

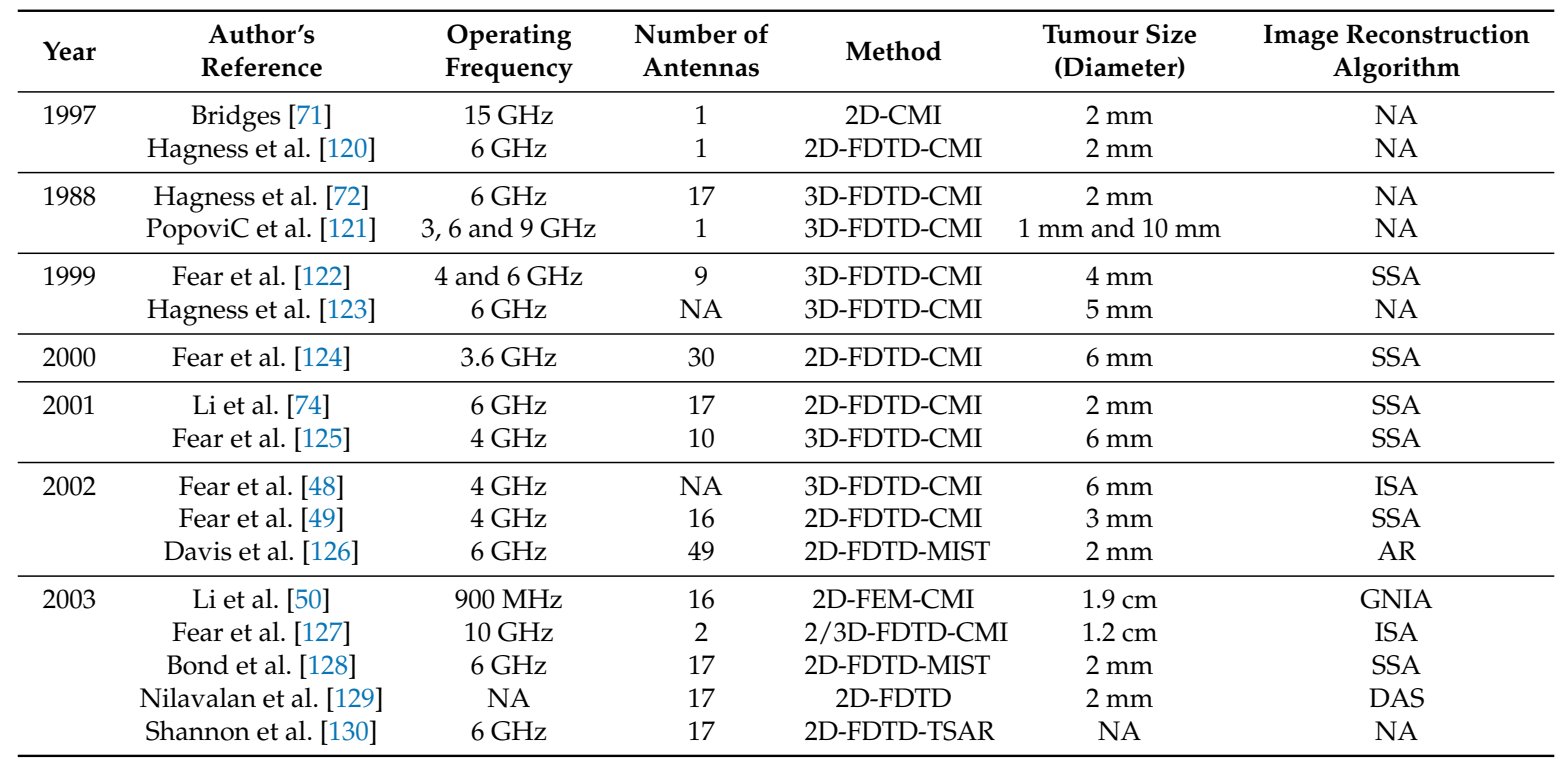


Table A1. Cont.

\begin{tabular}{|c|c|c|c|c|c|c|}
\hline Year & $\begin{array}{l}\text { Author's } \\
\text { Reference }\end{array}$ & $\begin{array}{l}\text { Operating } \\
\text { Frequency }\end{array}$ & $\begin{array}{l}\text { Number of } \\
\text { Antennas }\end{array}$ & Method & $\begin{array}{l}\text { Tumour Size } \\
\text { (Diameter) }\end{array}$ & $\begin{array}{l}\text { Image Reconstruction } \\
\text { Algorithm }\end{array}$ \\
\hline \multirow[t]{2}{*}{2003} & Davis et al. [131] & $6 \mathrm{GHz}$ & 17 & 2D-FDTD-MIST & $2 \mathrm{~mm}$ & SSA \\
\hline & Zhang et al. [45] & $800 \mathrm{MHz}$ & 32 & 2D-MOM & $1.4 \mathrm{~cm}$ & ISA \\
\hline \multirow[t]{5}{*}{2004} & Oral et al. [132] & $6 \mathrm{GHz}$ & 2 & 2D-FEM-CMI & $5 \mathrm{~mm}$ & MFA \\
\hline & Zhao et al. [133] & $3.2 \mathrm{GHz}$ & 24 & 2D-FDTD-CMI & $3 \mathrm{~mm}$ & SSA \\
\hline & Kosmas et al. [134] & $8 \mathrm{GHz}$ & 24 & 3D-FDTD & $4 \mathrm{~mm}$ & SSA \\
\hline & Li et al. [135] & $6 \mathrm{GHz}$ & 49 & 3D-FDTD-MIST & $4 \mathrm{~mm}$ & $\mathrm{AR}$ \\
\hline & Nilavalan et al. [136] & $6.5 \mathrm{GHz}$ & 16 & 2D-FDTD-CMI & $2 \mathrm{~mm}$ & SSA \\
\hline \multirow[t]{8}{*}{2005} & Davis et al. [137] & $6 \mathrm{GHz}$ & 24 & 3D-FDTD-CMI & $4 \mathrm{~mm}$ & GLRT \\
\hline & Kosmas et al. [138] & $2 \mathrm{GHz}$ & NA & 3D-FDTD-CMI & $3 \mathrm{~mm}$ & TR \\
\hline & Craddock et al. [139] & $3 \mathrm{GHz}$ & 16 & 2D-FDTD & $6 \mathrm{~mm}$ & IFFT \\
\hline & Guo et al. [140] & NA & $\mathrm{M}$ & 3D-FDTD-MIST & $4 \mathrm{~mm}$ & CRC \\
\hline & Li et al. [141] & $6 \mathrm{GHz}$ & M & 2D-FDTD-MIST & $2 \mathrm{~mm}$ & DAS and AR \\
\hline & Sill et al. [142] & $4 \mathrm{GHz}$ & 10 & 3D-FDTD-TSAR & $6 \mathrm{~mm}$ & NA \\
\hline & Nilavalan et al. [143] & $7 \mathrm{GHz}$ & $\mathrm{M}$ & 2D-FDTD & $4 \mathrm{~mm}$ & IFFT \\
\hline & Sill et al. [144] & $4 \mathrm{GHz}$ & 15 & 3D-FDTD-TSAR & $1 \mathrm{~cm}$ & $\mathrm{AR}$ \\
\hline \multirow[t]{13}{*}{2006} & Baang et al. [145] & NA & 5 & 2D-FDTD-CMI & $6 \mathrm{~mm}$ & GNIA \\
\hline & Bindu et al. [146] & $2.983 \mathrm{GHz}$ & 36 & 3D-FDTD-CMI & $2.5 \mathrm{~mm}$ & TSAA \\
\hline & Shao et al. [147] & $3.2 \mathrm{GHz}$ & 32 & 2D-FDTD-CMI & $6 \mathrm{~mm}$ & TSAA \\
\hline & Xie et al. [148] & $3.2 \mathrm{GHz}$ & 72 & 3D-FDTD-CMI & $4 \mathrm{~mm}$ & CRC \\
\hline & Bindu et al. [58] & $3000 \mathrm{MHz}$ & 36 & 3D-FDTD-CMI & $0.1 \mathrm{~cm}$ & TSAA \\
\hline & Bond et al. [149] & NA & 17 & 2D-FDTD-MIST & $2 \mathrm{~mm}$ & $\mathrm{AR}$ \\
\hline & Chen et al. [150] & $6 \mathrm{GHz}$ & 9 & 2D-FDTD & $4 \mathrm{~mm}$ & TOA \\
\hline & Craddock et al. [151] & $3 \mathrm{GHz}$ & 16 & 2D-FDTD & $1 \mathrm{~cm}$ & IFFT \\
\hline & Kosmas et al. [152] & $5 \mathrm{GHz}$ & 23 & 2D-FDTD & $3 \mathrm{~mm}$ & $\mathrm{TR}$ \\
\hline & Liu et al. [153] & $6 \mathrm{GHz}$ & 2 & 2D-FDTD & $1 \mathrm{~cm}$ & MFA \\
\hline & Xie et al. [154] & $5 \mathrm{GHz}$ & 72 & 2D-FDTD-CMI & $4 \mathrm{~mm}$ & DAS \\
\hline & Kosmas et al. [155] & NA & 22 & 3D-FDTD & $3 \mathrm{~mm}$ & TR \\
\hline & Zhi et al. [156] & NA & 13 & 2D-FDTD & $2 \mathrm{~mm}$ & SSA \\
\hline \multirow[t]{11}{*}{2007} & Xiao et al. [157] & $5 \mathrm{GHz}$ & 6 & 2D-FDTD-CMI & $6 \mathrm{~mm}$ & DAS \\
\hline & Ryu et al. [158] & $3000 \mathrm{MHz}$ & 36 & 3D-FDTD-CMI & $0.1 \mathrm{~cm}$ & TSAA \\
\hline & Tayel et al. [159] & $1 \mathrm{GHz}$ & 8 & 2D-FDTD-CMI & NA & CRC \\
\hline & Xiao et al. [160] & $5 \mathrm{GHz}$ & 6 & 2D-FDTD-CMI & $10 \mathrm{~mm}$ & DAS \\
\hline & Chen et al. [161] & $6 \mathrm{GHz}$ & 7 & 2D-FDTD-CMI & $0.6 \mathrm{~cm}$ & TR and GLRT \\
\hline & Abedin et al. [162] & $6 \mathrm{GHz}$ & 13 & 2D-FDTD-CMI & $1 \mathrm{~cm}$ & TR \\
\hline & Elsdon et al. [163] & $9.4 \mathrm{GHz}$ & 2 & 2D-Holographic & $2.5 \mathrm{~cm}$ & NA \\
\hline & Jafari et al. [164] & $5.5 \mathrm{GHz}$ & 2 & 2D-FDTD & $0.8 \mathrm{~cm}$ & NA \\
\hline & Jin et al. [165] & $9 \mathrm{GHz}$ & 2 & 2D-FDTD & $2 \mathrm{~mm}$ & TR \\
\hline & Klemm et al. [166] & $6 \mathrm{GHz}$ & 16 & 3D-FDTD & $4 \mathrm{~mm}$ and $10 \mathrm{~mm}$ & DAS \\
\hline & Zhuge et al. [167] & $5.5 \mathrm{GHz}$ & 10 & 3D-FDTD-MIST & $2 \mathrm{~mm}$ & $\mathrm{AR}$ \\
\hline \multirow[t]{14}{*}{2008} & Lim et al. [168] & $6.85 \mathrm{GHz}$ & 5 & 3D-FDTD-CMI & $2 \mathrm{~mm}$ & DMAS \\
\hline & Craddock et al. [169] & $9 \mathrm{GHz}$ & 16 & 3D-FDTD-CMI & $8 \mathrm{~mm}$ & DMAS \\
\hline & Kubota et al. [170] & $15 \mathrm{GHz}$ & 10 & 3D-FDTD-CMI & $13 \mathrm{~mm}$ & NA \\
\hline & Xiao et al. [171] & $3 \mathrm{GHz}$ & 9 & 2D-FDTD-CMI & $8 \mathrm{~mm}$ & Signal process \\
\hline & Takaichi et al. [172] & NA & 37 & 3D-FDTD-CMI & $1 \mathrm{~cm}$ & DMAS \\
\hline & Xiao et al. [173] & $6 \mathrm{GHz}$ & 7 & 2D-FDTD-CMI & $6 \mathrm{~mm}$ & Signal process \\
\hline & Klemm et al. [174] & $6 \mathrm{GHz}$ & 16 & 3D-FDTD & $7 \mathrm{~mm}$ and $10 \mathrm{~mm}$ & DAS \\
\hline & Chen et al. [175] & $8 \mathrm{GHz}$ & 7 & 2D-FDTD & $\begin{array}{c}0.6 \mathrm{~cm} \text { and } \\
0.4 \mathrm{~cm}\end{array}$ & TR \\
\hline & Davis et al. [176] & $6 \mathrm{GHz}$ & 1 & 3D-FDTD & $0.5 \mathrm{~cm}-2 \mathrm{~cm}$ & LDB \\
\hline & Jin et al. [177] & $5 \mathrm{GHz}$ & 14 & 2D-FDTD & $2 \mathrm{~mm}$ & TR \\
\hline & Chen et al. [178] & $1.5 \mathrm{GHz}$ & 7 & 2D-FDTD & $0.3 \mathrm{~cm}$ & CLEAN \\
\hline & Klemm et al. [179] & $5 \mathrm{GHz}$ & 16 & 2D-FDTD & $8 \mathrm{~mm}$ & TR \\
\hline & Winters et al. [180] & $6 \mathrm{GHz}$ & 40 & 3D-FDTD & NA & NA \\
\hline & Yu et al. [181] & $2.7 \mathrm{GHz}$ & 2 & 3D-FDTD & $5 \mathrm{~mm}$ & FFT \\
\hline \multirow[t]{11}{*}{2009} & Byrne et al. [182] & $7.5 \mathrm{GHz}$ & 14 & 2D-FDTD-CMI & $10 \mathrm{~mm}$ & DMAS \\
\hline & Kouzaki et al. [183] & $3 \mathrm{GHz}$ & 4 & 2D-FDTD-CMI & $30 \mathrm{~mm}$ & Imaging process \\
\hline & Liu et al. [184] & $3 \mathrm{GHz}$ & 4 & 2D-FDTD-CMI & $6 \mathrm{~mm}$ & DMAS \\
\hline & Xiao et al. [185] & $6 \mathrm{GHz}$ & 9 & 2D-FDTD-CMI & $6 \mathrm{~mm}$ & DMAS \\
\hline & Yang et al. [186] & NA & 9 & 2D-FDTD-CMI & $2 \mathrm{~mm}$ and $10 \mathrm{~mm}$ & Weighted DAS \\
\hline & Johnson et al. [187] & $2 \mathrm{GHz}$ & 25 & 2D-FDTD & $10 \mathrm{~mm}$ & FBTS \\
\hline & Khor et al. [188] & $8 \mathrm{GHz}$ & 1 & 2D-FDTD & $5 \mathrm{~mm}$ & SSA \\
\hline & Klemm et al. [189] & $6 \mathrm{GHz}$ & 16 & 3D-FDTD & $4 \mathrm{~mm}$ and $6 \mathrm{~mm}$ & DAS and RCB \\
\hline & Kurrant et al. [190] & $4 \mathrm{GHz}$ & 128 & 3D-FDTD & Irregular shaped & TOA \\
\hline & Yao et al. [191] & $1.575 \mathrm{GHz}$ & 8 & $2 \mathrm{D}$ & $10 \mathrm{~mm}$ & GA \\
\hline & Sajjadieh et al. [192] & NA & 24 & 2D-FDTD & Irregular shaped & TR \\
\hline
\end{tabular}


Table A1. Cont.

\begin{tabular}{|c|c|c|c|c|c|c|}
\hline Year & $\begin{array}{l}\text { Author's } \\
\text { Reference }\end{array}$ & $\begin{array}{l}\text { Operating } \\
\text { Frequency }\end{array}$ & $\begin{array}{l}\text { Number of } \\
\text { Antennas }\end{array}$ & Method & $\begin{array}{l}\text { Tumour Size } \\
\text { (Diameter) }\end{array}$ & $\begin{array}{l}\text { Image Reconstruction } \\
\text { Algorithm }\end{array}$ \\
\hline \multirow[t]{11}{*}{2010} & Kubot et al. [193] & $15 \mathrm{GHz}$ & 10 & 2D-CMI & $3 \mathrm{~mm}$ & NA \\
\hline & Shao et al. [194] & $3.2 \mathrm{GHz}$ & 26 & 2D-FDTD-CMI & $3 \mathrm{~mm}$ & A concise algorithm \\
\hline & Byrne et al. [195] & $7.5 \mathrm{GHz}$ & 53 & 2D-FDTD-CMI & 5,10 and $15 \mathrm{~mm}$ & DMAS \\
\hline & Deprez et al. [196] & $3.5 \mathrm{GHz}$ & 31 & 3D-FDTD-CMI & $7 \mathrm{~mm}$ & DMAS \\
\hline & Byrne et al. [197] & $7.5 \mathrm{GHz}$ & 53 & 2D-FDTD-CMI & 5,10 and $15 \mathrm{~mm}$ & $\mathrm{RCB}$ \\
\hline & $\begin{array}{l}\text { O'Halloranet } \\
\text { et al. [198] }\end{array}$ & $7.5 \mathrm{GHz}$ & 14 & 2D-FDTD-MIST & $5 \mathrm{~mm}$ & $\mathrm{AR}$ \\
\hline & Klemm et al. [199] & $6 \mathrm{GHz}$ & 31 & 3D-FDTD & $10 \mathrm{~mm}$ & NA \\
\hline & $\begin{array}{l}\text { Sarafianou } \\
\text { et al. [200] }\end{array}$ & $5 \mathrm{GHz}$ & 8 & 3D-FDTD & NA & MFA \\
\hline & Klemm et al. [201] & $6 \mathrm{GHz}$ & 31 & 3D-FDTD & $7 \mathrm{~mm}$ & DAS \\
\hline & Shea et al. [202] & $3 \mathrm{GHz}$ & 40 & 3D-FDTD & $\begin{array}{l}10 \mathrm{~mm} \text { and } \\
20 \mathrm{~mm}\end{array}$ & GNIA \\
\hline & Teo et al. [203] & $6 \mathrm{GHz}$ & 5 & 2D-FDTD & $5 \mathrm{~mm}$ & GNIA \\
\hline \multirow[t]{15}{*}{2011} & $\begin{array}{l}\text { Bialkowski } \\
\text { et al. [204] }\end{array}$ & $4 \mathrm{GHz}$ & 12 & 2D-FDTD-CMI & $4 \mathrm{~mm}$ & IFFT \\
\hline & $\begin{array}{l}\text { O'Halloran } \\
\text { et al. [205] }\end{array}$ & $7.5 \mathrm{GHz}$ & 20 & 2D-FDTD-CMI & 2.5 and $5 \mathrm{~mm}$ & DMAS \\
\hline & Liu et al. [206] & $5 \mathrm{GHz}$ & 8 & 2D-FDTD-CMI & $6 \mathrm{~mm}$ & $\mathrm{RCB}$ \\
\hline & Shao et al. [207] & $9.75 \mathrm{GHz}$ & 22 & 3D-FDTD-CMI & $3 \mathrm{~mm}$ & TOA \\
\hline & Zhang et al. [208] & $4.5 \mathrm{GHz}$ & 18 & 2D-FDTD-CMI & $9 \mathrm{~mm}$ & TSAS \\
\hline & Donelli et al. [209] & $2 \mathrm{GHz}$ & 31 & $3 \mathrm{D}$ & $10 \mathrm{~mm}$ & GA \\
\hline & Fumeaux et al. [210] & $0.5 \mathrm{GHz}$ & 31 & 3D-FEM & $6 \mathrm{~mm}$ & TOA \\
\hline & Golnabi et al. [211] & $1300 \mathrm{MHz}$ & 16 & 3D-FDTD & $3 \mathrm{~cm}$ & GNIA \\
\hline & $\begin{array}{c}\text { Henriksson } \\
\text { et al. [111] }\end{array}$ & $2 \mathrm{GHz}$ & 60 & 3D-FDTD & $3 \mathrm{~cm}$ & DAS \\
\hline & Liu et al. [206] & $5 \mathrm{GHz}$ & 7 & 2D-FDTD & $6 \mathrm{~mm}$ & $\mathrm{RCB}$ \\
\hline & Klemm et al. [212] & $2 \mathrm{GHz}$ & 60 & 3D-FDTD & NA & NA \\
\hline & Sajjadieh et al. [213] & NA & NA & 2D-FDTD & $2 \mathrm{~mm}$ & TR \\
\hline & $\begin{array}{l}\text { Sarafianou } \\
\text { et al. [214] }\end{array}$ & NA & 24 & 2D-FDTD & $1.2 \mathrm{~mm}$ & MFA \\
\hline & Zanoon et al. [215] & $5 \mathrm{GHz}$ & 8 & 2D-FDTD & $5 \mathrm{~mm}$ & $\mathrm{RCB}$ \\
\hline & Zeng et al. [216] & $4.5 \mathrm{GHz}$ & 16 & 2D-FDTD & $5 \mathrm{~mm}$ & IFFT \\
\hline \multirow[t]{7}{*}{2012} & Padhi et al. [217] & $5 \mathrm{GHz}$ & 36 & 2D-CMI & $2 \mathrm{~mm}$ & DMAS \\
\hline & Shaheen et al. [218] & $5 \mathrm{GHz}$ & 12 & 2D-FDTD-CMI & $2 \mathrm{~mm}$ & DMAS \\
\hline & Wang et al. [219] & $6.85 \mathrm{GHz}$ & 12 & 3D-FDTD-CMI & $2.5 \mathrm{~mm}$ & $\mathrm{AR}$ \\
\hline & Donelli et al. [220] & $3.5 \mathrm{GHz}$ & 16 & 3D-FDTD-CMI & NA & IFFT \\
\hline & Hossain et al. [221] & $5 \mathrm{GHz}$ & 29 & 3D-FDTD & $7 \mathrm{~mm}$ & TR \\
\hline & Deng et al. [222] & $3.5 \mathrm{GHz}$ & 15 & 3D-FDTD-CMI & $3.2 \mathrm{~mm}$ & DAS \\
\hline & Mohan et al. [223] & $3.5 \mathrm{GHz}$ & 21 & 3D-FDTD-CMI & NA & TR MUSIC \\
\hline \multirow[t]{14}{*}{2013} & Shahzad et al. [224] & $3.2 \mathrm{GHz}$ & 24 & 2D-FDTD-CMI & $3 \mathrm{~mm}$ & DAS \\
\hline & Sugitani et al. [225] & $6 \mathrm{GHz}$ & 16 & 3D-FDTD-CMI & $5 \mathrm{~mm}$ & NA \\
\hline & Xu et al. [226] & NA & 16 & 3D-FDTD-CMI & $3 \mathrm{~mm}$ & $\mathrm{RCB}$ \\
\hline & Sugitani et al. [227] & $6 \mathrm{GHz}$ & 16 & 3D-FDTD-CMI & $10 \mathrm{~mm}$ & NA \\
\hline & Bassi et al. [228] & $9 \mathrm{GHz}$ & 2 & 3D-FDTD-CMI & $6 \mathrm{~mm}$ and $9 \mathrm{~mm}$, & DAS \\
\hline & Fear et al. [78] & $4 \mathrm{GHz}$ & 2 & 2D-TSAR & $5 \mathrm{~mm}$ & NA \\
\hline & Hossain et al. [229] & $4.5 \mathrm{GHz}$ & 21 & 2D-FDTD & $5 \mathrm{~mm}$ & $\mathrm{AR}$ \\
\hline & Kurrant et al. [230] & $3.795 \mathrm{GHz}$ & 2 & 2D-FDTD & NA & TOF \\
\hline & Kwon et al. [81] & $6 \mathrm{GHz}$ & 16 & 3D-FDTD & $3 \mathrm{~mm}$ & DAS \\
\hline & Porter et al. [80] & $2 \mathrm{GHz}$ & 16 & 3D-FDTD & $1 \mathrm{~cm}$ & DAS \\
\hline & Ruvio et al. [231] & $1 \mathrm{GHz}$ & 12 & 2D-FDTD & $5 \mathrm{~mm}$ & MUSIC \\
\hline & $\begin{array}{l}\text { Sarafianou } \\
\text { et al. [232] }\end{array}$ & $2 \mathrm{GHz}$ & 31 & 2D-FDTD & $20 \mathrm{~mm}$ & DAS and MUSIC \\
\hline & $\begin{array}{l}\text { Sarafianou } \\
\text { et al. [233] }\end{array}$ & $2 \mathrm{GHz}$ & 31 & 2D-FDTD & $20 \mathrm{~mm}$ & SSR \\
\hline & Xia et al. [234] & $5 \mathrm{GHz}$ & 9 & 3D-FDTD & $2 \mathrm{~mm}$ & DCRCB \\
\hline \multirow[t]{7}{*}{2014} & Elahi et al. [235] & $6 \mathrm{GHz}$ & 50 & 3D-FDTD-CMI & $8 \mathrm{~mm}$ & $\mathrm{AR}$ \\
\hline & Kikkawa et al. [236] & $5 \mathrm{GHz}$ & 6 & 3D-FDTD-CMI & NA & NA \\
\hline & Sugitani et al. [237] & $6 \mathrm{GHz}$ & 16 & 3D-FDTD-CMI & $5 \mathrm{~mm}$ & NA \\
\hline & Bahrami et al. [238] & $1.5 \mathrm{GHz}$ & 16 & 3D-FDTD & NA & NA \\
\hline & Moll et al. [239] & $2 \mathrm{GHz}$ & 31 & 3D-FDTD & $4 \mathrm{~mm}$ & DAS \\
\hline & Song et al. [240] & $6 \mathrm{GHz}$ & 9 & 3D-FDTD & $6 \mathrm{~mm}$ & DCRCB \\
\hline & Ünal et al. [240] & $4.5 \mathrm{GHz}$ & 7 & 3D-FEM & $2 \mathrm{~mm}$ & DAS \\
\hline
\end{tabular}


Table A1. Cont.

\begin{tabular}{|c|c|c|c|c|c|c|}
\hline Year & $\begin{array}{l}\text { Author's } \\
\text { Reference }\end{array}$ & $\begin{array}{l}\text { Operating } \\
\text { Frequency }\end{array}$ & $\begin{array}{l}\text { Number of } \\
\text { Antennas }\end{array}$ & Method & $\begin{array}{l}\text { Tumour Size } \\
\text { (Diameter) }\end{array}$ & $\begin{array}{c}\text { Image Reconstruction } \\
\text { Algorithm }\end{array}$ \\
\hline \multirow[t]{15}{*}{2015} & Jalilvand et al. [241] & $2.5 \mathrm{GHz}$ & 16 & 3D-FDTD-CMI & $10 \mathrm{~mm}$ & DMAS \\
\hline & Kikkawa et al. [242] & $4.5 \mathrm{GHz}$ & 16 & 3D-FDTD-CMI & $10 \mathrm{~mm}$ & NA \\
\hline & Kono et al. [243] & NA & 16 & 3D-FDTD-CMI & $10 \mathrm{~mm}$ & NA \\
\hline & Song et al. [244] & $6 \mathrm{GHz}$ & 16 & 3D-FDTD-CMI & $1 \mathrm{~cm}$ & NA \\
\hline & Xiao et al. [245] & NA & 8 & 3D-FDTDI-CM & $4 \mathrm{~mm}$ & DCRCB \\
\hline & Song et al. [246] & NA & 16 & 3D-FDTD-CMI & $4 \mathrm{~mm}$ & DAS \\
\hline & Elahi et al. [247] & NA & 16 & 3D-FDTD-CMI & NA & MDAS \\
\hline & $\begin{array}{l}\text { Bahramiabarghouei } \\
\text { et al. [248] }\end{array}$ & $3 \mathrm{GHz}$ & 16 & 3D-FDTD & NA & DAS \\
\hline & Byrne et al. [249] & $3.2 \mathrm{GHz}$ & 31 & 3D-FDTD & $10 \mathrm{~mm}$ & DAS \\
\hline & Conceição et al. [250] & $5 \mathrm{GHz}$ & 60 & 3D & NA & $\mathrm{AR}$ \\
\hline & Khan et al. [251] & $7.3 \mathrm{GHz}$ & 9 & $3 \mathrm{D}$ & NA & DAS \\
\hline & Salleh et al. [252] & $8.8 \mathrm{GHz}$ & 1 & 3D-MIST & NA & IFFT \\
\hline & Santorelli et al. [82] & $3 \mathrm{GHz}$ & 16 & 3D & $1 \mathrm{~cm}$ & DMAS \\
\hline & Li et al. [253] & $6 \mathrm{GHz}$ & 12 & 3D-CMI & $4 \mathrm{~mm}$ & EEMD \\
\hline & Yin et al. [254] & $6.85 \mathrm{GHz}$ & 24 & 3D-FDTD & $10 \mathrm{~mm}$ & RAR \\
\hline \multirow[t]{9}{*}{2016} & $\begin{array}{l}\text { O'Loughlin } \\
\text { et al. [255] }\end{array}$ & $6 \mathrm{GHz}$ & 20 & 3D-FDTD-CMI & $3 \mathrm{~mm}$ and $5 \mathrm{~mm}$ & DAS \\
\hline & Song et al. [256] & $15 \mathrm{GHz}$ & 16 & 3D-FDTD-CMI & $5 \mathrm{~mm}$ & NA \\
\hline & Medina et al. [257] & $9 \mathrm{GHz}$ & 1 & 2D-FDTD-CMI & $15 \mathrm{~mm}$ & DAS \\
\hline & Song et al. [258] & NA & 16 & 3D-FDTD-CMI & $1 \mathrm{~cm}$ & NA \\
\hline & Abbosh et al. [259] & $2 \mathrm{GHz}$ & 16 & 3D-FEM & $1.5 \mathrm{~cm}$ & DAS \\
\hline & Bah et al. [260] & $4 \mathrm{GHz}$ & 4 & 3D & NA & TR-MUSIC \\
\hline & Kwon et al. [261] & $4.7 \mathrm{GHz}$ & 16 & $3 \mathrm{D}$ & $3 \mathrm{~mm}$ & DAS \\
\hline & Li et al. [262] & $1 \mathrm{GHz}$ & 16 & $3 \mathrm{D}$ & NA & DAS \\
\hline & Porter et al. [83] & $3 \mathrm{GHz}$ & 16 & $3 \mathrm{D}$ & NA & DMAS \\
\hline \multirow[t]{11}{*}{2017} & $\begin{array}{l}\text { Mozaffarzadeh } \\
\text { et al. [263] }\end{array}$ & $7 \mathrm{GHz}$ & NA & 3D-FDTD & NA & DDMAS \\
\hline & Ji et al. [264] & NA & 18 & 3D-FDTD & $10 \mathrm{~mm}$ & CMI \\
\hline & Aydın et al. [265] & $6 \mathrm{GHz}$ & 1 & 3D-FEM & $4 \mathrm{~mm}$ & NA \\
\hline & Byrne et al. [266] & $6 \mathrm{GHz}$ & 60 & 3D & $7 \mathrm{~mm}$ & DAS \\
\hline & Elahi et al. [267] & $4 \mathrm{GHz}$ & 1 & $3 \mathrm{D}$ & $16 \mathrm{~mm}$ & $\mathrm{AR}$ \\
\hline & Elahi et al. [268] & $6 \mathrm{GHz}$ & 25 & 3D-FDTD & $15 \mathrm{~mm}$ & $\mathrm{AR}$ \\
\hline & $\begin{array}{c}\text { KaramFard } \\
\text { et al. [269] }\end{array}$ & $5 \mathrm{GHz}$ & 73 & 2D-FDTD & $14 \mathrm{~mm}$ & DMAS \\
\hline & Hossain et al. [270] & $3 \mathrm{GHz}$ & 115 & 3D-FDTD & $10 \mathrm{~mm}$ & TR-MUSIC \\
\hline & Kranold et al. [271] & $1 \mathrm{GHz}$ & 16 & 3D-FDTD & $10 \mathrm{~mm}$ & DMAS \\
\hline & Mirza et al. [272] & $6 \mathrm{GHz}$ & 2 & 3D & $4 \mathrm{~mm}$ & ISA \\
\hline & Mirza et al. [272] & $6 \mathrm{GHz}$ & 2 & $3 \mathrm{D}$ & $4 \mathrm{~mm}$ & ISA \\
\hline
\end{tabular}

Table A2. A comparison between innovative algorithms and methodologies for breast cancer imaging.

\begin{tabular}{|c|c|c|c|}
\hline Year & Authors and Reference & Frequency & Method \\
\hline 2004 & Zhang et al. [85] & $800 \mathrm{MHz}$ & $\begin{array}{l}\text { 3-D nonlinear inverse scattering based on the } \\
\text { combination of the contrast source inversion and the } \\
\text { fast Fourier transform algorithm. }\end{array}$ \\
\hline 2010 & Bozza et al. [86] & $0.5-20 \mathrm{GHz}$ & The no-sampling linear sampling \\
\hline 2011 & Bellizzi et al. [87] & $2 \mathrm{GHz}$ & Magnetic nanoparticles as the contrast agent \\
\hline 2012 & Bucci et al. [88] & $0.1-6 \mathrm{GHz}$ & Magnetic nanoparticles as the contrast agent \\
\hline 2012 & Scapaticci et al. [89] & $1-4 \mathrm{GHz}$ & $\begin{array}{l}\text { A full-wave inversion method, based on } \\
\text { wavelet transform }\end{array}$ \\
\hline 2014 & Scapaticci et al. [90] & $2 \mathrm{GHz}$ & Magnetic nanoparticles as the contrast agent \\
\hline 2014 & Baran et al. [91] & $1.45-5.59 \mathrm{GHz}$ & $\begin{array}{l}\text { Microwave tomography and a radar-based } \\
\text { region estimation }\end{array}$ \\
\hline 2015 & Scapaticci et al. [92] & $1-3 \mathrm{GHz}$ & Distorted Born inversion method \\
\hline
\end{tabular}


Table A2. Cont.

\begin{tabular}{|c|c|c|c|}
\hline Year & Authors and Reference & Frequency & Method \\
\hline 2016 & Bevacqua et al. [93] & $2 \mathrm{GHz}$ & Magnetic nanoparticles as the contrast agent \\
\hline 2017 & Palmeri et al. [94] & $1-3 \mathrm{GHz}$ & Wavelet basis expansion \\
\hline 2017 & Neira et al. [95] & $0.5-3.5 \mathrm{GHz}$ & Spatial prior inverse scattering \\
\hline 2017 & Miao et al. [96] & $1-3.5 \mathrm{GHz}$ & Distorted Born iterative method \\
\hline 2019 & Ambrosanio et al. [97] & $0.5-3.5 \mathrm{GHz}$ & $\begin{array}{l}\text { Compressive sensing with distorted Born } \\
\text { iterative method }\end{array}$ \\
\hline 2019 & Bevacqua et al. [98] & $1-4 \mathrm{GHz}$ & Distorted iterated virtual experiments \\
\hline 2015 & Maffongelli et al. [99] & $0.5-20 \mathrm{GHz}$ & $\begin{array}{l}\text { Inverse scattering based on a inexact } \\
\text { Newton-type algorithm }\end{array}$ \\
\hline 2017 & Bucci et al. [100] & $2-3 \mathrm{GHz}$ & Magnetic nanoparticles \\
\hline 2018 & Maffongelli et al. [101] & $1.5-6 \mathrm{GHz}$ & $\begin{array}{l}\text { A hybrid inversion algorithm, which combines a } \\
\text { qualitative and a quantitative inversion procedure }\end{array}$ \\
\hline
\end{tabular}

\section{References}

1. American Cancer Society. Cancer Facts E Figures 2020; American Cancer Society: Atlanta, GA, USA, 2020. Available online: https://www.cancer.org/content/dam/cancer-org/research/cancer \-facts-and-statistics/ annual-cancer-facts-and-figures/2020/cancer-facts-and-figures-2020.pdf (accessed on 18 April 2020).

2. Berg, W.A.; Gutierrez, L.; NessAiver, M.S.; Carter, W.B.; Bhargavan, M.; Lewis, R.S.; Ioffe, O.B. Diagnostic accuracy of mammography, clinical examination, US, and MR imaging in preoperative assessment of breast cancer. Radiology 2004, 233, 830-849. [CrossRef] [PubMed]

3. Independent UK Panel on Breast Cancer Screening and Others-The benefits and harms of breast cancer screening: An independent review. Lancet 2012, 380, 1778-1786. [CrossRef]

4. de Gonzalez, A.B.; Darby, S. Risk of cancer from diagnostic X-rays: Estimates for the UK and 14 other countries. Lancet 2004, 363, 345-351. [CrossRef]

5. Ronckers, C.M.; Erdmann, C.A.; Land, C.E. Radiation and breast cancer: A review of current evidence. Breast Cancer Res. 2004, 7, 21. [CrossRef]

6. Barh, D. Omics Approaches in Breast Cancer: Towards Next-Generation Diagnosis, Prognosis and Therapy; Springer: Delhi, India, 2014.

7. Moore, A. The Practice of Breast Ultrasound: Techniques, Findings, Differential Diagnosis. Ultrasound Med. Biol. 2010, 36, 358. [CrossRef]

8. Kwon, S.; Lee, S. Recent advances in microwave imaging for breast cancer detection. Int. J. Biomed. Imaging 2016, 2016, 5054912. [CrossRef] [PubMed]

9. Orel, S.G.; Schnall, M.D. MR imaging of the breast for the detection, diagnosis, and staging of breast cancer. Radiology 2001, 220, 13-30. [CrossRef]

10. Aldhaeebi, M.A.; Almoneef, T.S.; Attia, H.; Ramahi, O.M. Near-Field Microwave Loop Array Sensor for Breast Tumor Detection. IEEE Sens. J. 2019, 19, 11867-11872. [CrossRef]

11. Aldhaeebi, M.A.; Almoneef, T.S.; Attia, H.; Ramahi, O.M. Electrically Small Magnetic Probe with PCA for Near-Field Microwave Breast Tumors Detection. Prog. Electromagn. Res. M 2019, 48, 177-186. [CrossRef]

12. Nikolova, N.K. Microwave imaging for breast cancer. IEEE Microw. Mag. 2011, 12, 78-94. [CrossRef]

13. Chaudhary, S.; Mishra, R.; Swarup, A.; Thomas, J.M. Dielectric properties of normal \& malignant human breast tissues at radiowave \& microwave frequencies. Indian J. Biochem. Biophys. 1984, 21, 76-79. [PubMed]

14. Pozar, D.M. Microwave Engineering; John Wiley \& Sons: Hoboken, NJ, USA, 2009.

15. Surowiec, A.J.; Stuchly, S.S.; Barr, J.R.; Swarup, A. Dielectric properties of breast carcinoma and the surrounding tissues. IEEE Trans. Biomed. Eng. 1988, 35, 257-263. [CrossRef]

16. Campbell, A.; Land, D. Dielectric properties of female human breast tissue measured in vitro at $3.2 \mathrm{GHz}$. Phys. Med. Biol. 1992, 37, 193. [CrossRef] [PubMed] 
17. Joines, W.T.; Zhang, Y.; Li, C.; Jirtle, R.L. The measured electrical properties of normal and malignant human tissues from 50 to $900 \mathrm{MHz}$. Med. Phys. 1994, 21, 547-550. [CrossRef] [PubMed]

18. Choi, J.W.; Cho, J.; Lee, Y.; Yim, J.; Kang, B.; Oh, K.K.; Jung, W.H.; Kim, H.J.; Cheon, C.; Lee, H.D.; et al. Microwave detection of metastasized breast cancer cells in the lymph node; potential application for sentinel lymphadenectomy. Breast Cancer Res. Treat. 2004, 86, 107-115. [CrossRef]

19. Lazebnik, M.; Popovic, D.; McCartney, L.; Watkins, C.B.; Lindstrom, M.J.; Harter, J.; Sewall, S.; Ogilvie, T.; Magliocco, A.; Breslin, T.M.; et al. A large-scale study of the ultra-wideband microwave dielectric properties of normal, benign and malignant breast tissues obtained from cancer surgeries. Phys. Med. Biol. 2007, 52, 6093. [CrossRef]

20. Halter, R.J.; Zhou, T.; Meaney, P.M.; Hartov, A.; Barth, R.J., Jr.; Rosenkranz, K.M.; Wells, W.A.; Kogel, C.A.; Borsic, A.; Rizzo, E.J.; et al. The correlation of in vivo and ex vivo tissue dielectric properties to validate electromagnetic breast imaging: Initial clinical experience. Physiol. Meas. 2009, 30, S121. [CrossRef]

21. Sugitani, T.; Kubota, S.I.; Kuroki, S.I.; Sogo, K.; Arihiro, K.; Okada, M.; Kadoya, T.; Hide, M.; Oda, M.; Kikkawa, T. Complex permittivities of breast tumour tissues obtained from cancer surgeries. Appl. Phys. Lett. 2014, 104, 253702. [CrossRef]

22. Martellosio, A.; Pasian, M.; Bozzi, M.; Perregrini, L.; Mazzanti, A.; Svelto, F.; Summers, P.; Renne, G.; Bellomi, M. 0.5-50 GHz dielectric characterisation of breast cancer tissues. Electron. Lett. 2015, 51, 974-975. [CrossRef]

23. Martellosio, A.; Pasian, M.; Bozzi, M.; Perregrini, L.; Mazzanti, A.; Svelto, F.; Summers, P.E.; Renne, G.; Preda, L.; Bellomi, M. Dielectric properties characterization from 0.5 to $50 \mathrm{GHz}$ of breast cancer tissues. IEEE Trans. Microw. Theory Tech. 2017, 65, 998-1011. [CrossRef]

24. Salahuddin, S.; Porter, E.; Meaney, P.M.; O'Halloran, M. Effect of logarithmic and linear frequency scales on parametric modelling of tissue dielectric data. Biomed. Phys. Eng. Express 2017, 3, 015020. [CrossRef] [PubMed]

25. Meaney, P.M.; Gregory, A.P.; Epstein, N.R.; Paulsen, K.D. Microwave open-ended coaxial dielectric probe: Interpretation of the sensing volume re-visited. BMC Med. Phys. 2014, 14, 3. [CrossRef] [PubMed]

26. Porter, E.; O'Halloran, M. Investigation of histology region in dielectric measurements of heterogeneous tissues. IEEE Trans. Antennas Propag. 2017, 65, 5541-5552. [CrossRef]

27. Salahuddin, S.; La Gioia, A.; Elahi, M.A.; Porter, E.; O’Halloran, M.; Shahzad, A. Comparison of in-vivo and ex-vivo dielectric properties of biological tissues. In Proceedings of the 2017 International Conference on Electromagnetics in Advanced Applications (ICEAA), Verona, Italy, 11-15 September 2017; pp. 582-585.

28. Cheng, Y.; Fu, M. Dielectric properties for non-invasive detection of normal, benign, and malignant breast tissues using microwave theories. Thorac. Cancer 2018, 9, 459-465. [CrossRef]

29. Hussein, M.; Awwad, F.; Jithin, D.; El Hasasna, H.; Athamneh, K.; Iratni, R. Breast cancer cells exhibits specific dielectric signature in vitro using the open-ended coaxial probe technique from $200 \mathrm{MHz}$ to $13.6 \mathrm{GHz}$. Sci. Rep. 2019, 9, 4681. [CrossRef]

30. O'Loughlin, D.; O'Halloran, M.; Moloney, B.M.; Glavin, M.; Jones, E.; Elahi, M.A. Microwave breast imaging: Clinical advances and remaining challenges. IEEE Trans. Biomed. Eng. 2018, 65, 2580-2590. [CrossRef] [PubMed]

31. Bellizzi, G.; Bucci, O.M.; Capozzoli, A. Broadband spectroscopy of the electromagnetic properties of aqueous ferrofluids for biomedical applications. J. Magn. Magn. Mater. 2010, 322, 3004-3013. [CrossRef]

32. Bellizzi, G.; Bucci, O.M. A Novel Measurement Technique for the Broadband Characterization of Diluted Water Ferrofluids for Biomedical Applications. IEEE Trans. Magn. 2013, 49, 2903-2912. [CrossRef]

33. Bellizzi, G.; Bellizzi, G.G.; Bucci, O.M.; Crocco, L.; Helbig, M.; Ley, S.; Sachs, J. Optimization of the Working Conditions for Magnetic Nanoparticle-Enhanced Microwave Diagnostics of Breast Cancer. IEEE Trans. Biomed. Eng. 2018, 65, 1607-1616. [CrossRef] [PubMed]

34. Catapano, I.; Donato, L.D.; Crocco, L.; Bucci, O.M.; Morabito, A.F.; Isernia, T.; Massa, R. On Quantitative Microwave Tomography of Female Breast. Prog. Electromagn. Res. 2009, 97, 75-93. [CrossRef]

35. Fear, E.C.; Hagness, S.C.; Meaney, P.M.; Okoniewski, M.; Stuchly, M.A. Enhancing breast tumour detection with near-field imaging. IEEE Microw. Mag. 2002, 3, 48-56. [CrossRef]

36. Larsen, L.E.; Jacobi, J.H. Medical Applications of Microwave Imaging; Technical Report; Institute of Electrical and Electronics Engineers Inc.: New York, NY, USA, 1985. 
37. Conceição, R.C.; Mohr, J.J.; O’Halloran, M. An Introduction to Microwave Imaging for Breast Cancer Detection; Springer International Publishing: Basel, Switzerland, 2016.

38. Bocquet, B.; Van de Velde, J.; Mamouni, A.; Leroy, Y.; Giaux, G.; Delannoy, J.; Delvalee, D. Microwave radiometric imaging at $3 \mathrm{GHz}$ for the exploration of breast tumours. IEEE Trans. Microw. Theory Tech. 1990, 38, 791-793. [CrossRef]

39. Mouty, S.; Bocquet, B.; Ringot, R.; Rocourt, N.; Devos, P. Microwave radiometric imaging (MWI) for the characterisation of breast tumours. Eur. Phys. J. Appl. Phys. 2000, 10, 73-78. [CrossRef]

40. Wang, X.; Xin, H.; Bauer, D.; Witte, R. Microwave induced thermal acoustic imaging modeling for potential breast cancer detection. In Proceedings of the 2011 IEEE International Symposium on Antennas and Propagation (APSURSI), Spokane, WA, USA, 3-8 July 2011.

41. Song, J.; Zhao, Z.; Wu, J.; Zhu, X.; Nie, Z.; Liu, Q.H. Thermo-acoustic imaging for different breast tissues in microwave induced thermo-acoustic tomography system. In Proceedings of the 2013 IEEE Antennas and Propagation Society International Symposium (APSURSI), Orlando, FL, USA, 7-13 July 2013; pp. 2032-2033.

42. Pichot, C.; Jofre, L.; Peronnet, G.; Bolomey, J. Active microwave imaging of inhomogeneous bodies. IEEE Trans. Antennas Propag. 1985, 33, 416-425. [CrossRef]

43. Chew, W. Imaging and inverse problems in electromagnetics. In Advances in Computational Electrodynamics: The Finite-Difference Time-Domain Method; Artech House: Norwood, MA, USA, 1998; pp. 653-702.

44. Meaney, P.M.; Fanning, M.W.; Li, D.; Poplack, S.P.; Paulsen, K.D. A clinical prototype for active microwave imaging of the breast. IEEE Trans. Microw. Theory Tech. 2000, 48, 1841-1853.

45. Zhang, Z.Q.; Liu, Q.H.; Xiao, C.; Ward, E.; Ybarra, G.; Joines, W.T. Microwave breast imaging: 3-D forward scattering simulation. IEEE Trans. Biomed. Eng. 2003, 50, 1180-1189. [CrossRef]

46. Meaney, P.M.; Fanning, M.W.; di Florio-Alexander, R.M.; Kaufman, P.A.; Geimer, S.D.; Zhou, T.; Paulsen, K.D. Microwave tomography in the context of complex breast cancer imaging. In Proceedings of the 2010 Annual International Conference of the IEEE Engineering in Medicine and Biology Society (EMBC), Buenos Aires, Argentina, 31 August-4 September 2010; pp. 3398-3401.

47. Kwon, K.C.; Lim, Y.T.; Kim, C.H.; Kim, N.; Park, C.; Yoo, K.H.; Son, S.H.; Jeon, S.I. Microwave tomography analysis system for breast tumour detection. J. Med. Syst. 2012, 36, 1757-1767. [CrossRef]

48. Fear, E.C.; Li, X.; Hagness, S.C.; Stuchly, M.A. Confocal microwave imaging for breast cancer detection: Localization of tumours in three dimensions. IEEE Trans. Biomed. Eng. 2002, 49, 812-822. [CrossRef]

49. Fear, E.; Low, A.; Sill, J.; Stuchly, M.A. Microwave system for breast tumour detection: Experimental concept evaluation. In Proceedings of the IEEE Antennas and Propagation Society International Symposium, San Antonio, TX, USA, 16-21 June 2002; Volume 1, pp. 819-822.

50. Li, D.; Meaney, P.M.; Paulsen, K.D. Conformal microwave imaging for breast cancer detection. IEEE Trans. Microw. Theory Tech. 2003, 51, 1179-1186.

51. Fear, E.C.; Meaney, P.M.; Stuchly, M.A. Microwaves for breast cancer detection. IEEE Potentials 2003, 22, 12-18. [CrossRef]

52. Li, D.; Meaney, P.M.; Raynolds, T.; Pendergrass, S.A.; Fanning, M.W.; Paulsen, K.D. Parallel-detection microwave spectroscopy system for breast imaging. Rev. Sci. Instrum. 2004, 75, 2305-2313. [CrossRef]

53. Meaney, P.M.; Paulsen, K.D.; Hartov, A.; Crane, R.K. An active microwave imaging system for reconstruction of 2-D electrical property distributions. IEEE Trans. Biomed. Eng. 1995, 42, 1017-1026. [CrossRef] [PubMed]

54. Bulyshev, A.E.; Semenov, S.Y.; Souvorov, A.E.; Svenson, R.H.; Nazarov, A.G.; Sizov, Y.E.; Tatsis, G.P. Computational modeling of three-dimensional microwave tomography of breast cancer. IEEE Trans. Biomed. Eng. 2001, 48, 1053-1056. [CrossRef] [PubMed]

55. Semenov, S. Microwave tomography: Review of the progress towards clinical applications. Philos. Trans. R. Soc. Lond. A Math. Phys. Eng. Sci. 2009, 367, 3021-3042. [CrossRef]

56. Souvorov, A.E.; Bulyshev, A.E.; Semenov, S.Y.; Svenson, R.H.; Tatsis, G.P. Two-dimensional computer analysis of a microwave flat antenna array for breast cancer tomography. IEEE Trans. Microw. Theory Tech. 2000, 48, 1413-1415. [CrossRef]

57. Fear, E.; Stuchly, M. Microwave detection of breast cancer. IEEE Trans. Microw. Theory Tech. 2000, $48,1854-1863$.

58. Bindu, G.N.; Abraham, S.J.; Lonappan, A.; Thomas, V.; Aanandan, C.K.; Mathew, K. Active microwave imaging for breast cancer detection. Prog. Electromagn. Res. 2006, 58, 149-169. [CrossRef] 
59. Jofre, L.; Hawley, M.S.; Broquetas, A.; de Los Reyes, E.; Ferrando, M.; Elias-Fuste, A.R. Medical imaging with a microwave tomographic scanner. IEEE Trans. Biomed. Eng. 1990, 37, 303-312. [CrossRef]

60. Meaney, P.M.; Paulsen, K.D.; Pogue, B.W.; Miga, M.I. Microwave image reconstruction utilizing log-magnitude and unwrapped phase to improve high-contrast object recovery. IEEE Trans. Med. Imaging 2001, 20, 104-116. [CrossRef]

61. Noghanian, S.; Sabouni, A.; Desell, T.; Ashtari, A. Microwave Tomography: Global Optimization, Parallelization and Performance Evaluation; Springer: New York, NY, USA, 2014.

62. Semenov, S.Y.; Bulyshev, A.E.; Souvorov, A.E.; Svenson, R.H.; Sizov, Y.E.; Vorisov, V.; Posukh, V.G.; Kozlov, I.M.; Nazarov, A.G.; Tatsis, G.P. Microwave tomography: Theoretical and experimental investigation of the iteration reconstruction algorithm. IEEE Trans. Microw. Theory Tech. 1998, 46, 133-141. [CrossRef]

63. Meaney, P.M.; Demidenko, E.; Yagnamurthy, N.K.; Li, D.; Fanning, M.W.; Paulsen, K.D. A two-stage microwave image reconstruction procedure for improved internal feature extraction. Med. Phys. 2001, 28, 2358-2369. [CrossRef] [PubMed]

64. Li, D.; Meaney, P.M.; Fanning, M.; Fang, Q.; Pendergrass, S.A.; Raynolds, T. Spectrum analysis of microwave breast examination data and reconstructed images. In Proceedings of the 2002 IEEE International Symposium on Biomedical Imaging, Washington, DC, USA, 7-10 July 2002; pp. 62-65.

65. Giokaris, N.; Loudos, G.; Maintas, D.; Papapanagiotou, D.; Nikita, K.; Uzunoglu, N.; Karabarbounis, A.; Papanicolas, C.; Stiliaris, E.; Archimandritis, S.; et al. Imaging of breast phantoms using a high-resolution position sensitive photomultiplier tube. Nucl. Instrum. Methods Phys. Res. Sect. A Accel. Spectrom. Detect. Assoc. Equip. 2003, 497, 141-149. [CrossRef]

66. Fang, Q.; Meaney, P.M.; Paulsen, K.D. Microwave image reconstruction of tissue property dispersion characteristics utilizing multiple-frequency information. IEEE Trans. Microw. Theory Tech. 2004, 52, 1866-1875. [CrossRef]

67. Grzegorczyk, T.M.; Meaney, P.M.; Kaufman, P.A.; Paulsen, K.D. Fast 3-D tomographic microwave imaging for breast cancer detection. IEEE Trans. Med. Imaging 2012, 31, 1584-1592. [CrossRef]

68. Son, S.H.; Simonov, N.; Kim, H.J.; Lee, J.M.; Jeon, S.I. Preclinical prototype development of a microwave tomography system for breast cancer detection. ETRI J. 2010, 32, 901-910. [CrossRef]

69. Pagliari, D.J.; Pulimeno, A.; Vacca, M.; Tobon, J.A.; Vipiana, F.; Casu, M.R.; Solimene, R.; Carloni, L.P. A low-cost, fast, and accurate microwave imaging system for breast cancer detection. In Proceedings of the 2015 IEEE Biomedical Circuits and Systems Conference (BioCAS), Atlanta, GA, USA, 22-24 October 2015; pp. 1-4.

70. Jeon, S.I.; Kim, B.R.; Son, S.H. Clinical trial of Microwave Tomography imaging. In Proceedings of the IEEE URSI Asia-Pacific Radio Science Conference (URSI AP-RASC), Seoul, Korea, 21-25 August 2016; pp. 1-2.

71. Bridges, J.E. Non-Invasive System for Breast Cancer Detection. U.S. Patent 5,704,355, 6 January 1998.

72. Hagness, S.C.; Taflove, A.; Bridges, J.E. Two-dimensional FDTD analysis of a pulsed microwave confocal system for breast cancer detection: Fixed-focus and antenna-array sensors. IEEE Trans. Biomed. Eng. 1998, 45, 1470-1479. [CrossRef]

73. Fear, E.C. Microwave imaging of the breast. Technol. Cancer Res. Treat. 2005, 4, 69-82. [CrossRef]

74. Li, X.; Hagness, S.C. A confocal microwave imaging algorithm for breast cancer detection. IEEE Microw. Wirel. Compon. Lett. 2001, 11, 130-132.

75. Porter, E. Microwave breast tumour detection: Simulation and design of experiments with tissue phantoms. Masters Abstr. Int. 2010, 49, 5.

76. Klemm, M.; Craddock, I.; Leendertz, J.; Preece, A.; Benjamin, R. Experimental and clinical results of breast cancer detection using UWB microwave radar. In Proceedings of the 2008 IEEE Antennas and Propagation Society International Symposium, San Diego, CA, USA, 5-11 July 2008; pp. 1-4.

77. Zhurbenko, V.; Rubæk, T.; Krozer, V.; Meincke, P. Design and realisation of a microwave three-dimensional imaging system with application to breast-cancer detection. IET Microw. Antennas Propag. 2010, 4, 2200-2211. [CrossRef]

78. Fear, E.C.; Bourqui, J.; Curtis, C.; Mew, D.; Docktor, B.; Romano, C. Microwave breast imaging with a monostatic radar-based system: A study of application to patients. IEEE Trans. Microw. Theory Tech. 2013, 61, 2119-2128. [CrossRef] 
79. Kikkawa, T.; Toya, A.; Kubota, S.; Hafiz, M.; Azhari, A.; Sasaki, N. IR-UWB-CMOS circuits for breast cancer detection. In Proceedings of the 2012 6th European Conference on Antennas and Propagation (EUCAP), Prague, Czech Republic, 26-30 March 2012; pp. 1758-1760.

80. Porter, E.; Kirshin, E.; Santorelli, A.; Coates, M.; Popović, M. Time-domain multistatic radar system for microwave breast screening. IEEE Antennas Wirel. Propag. Lett. 2013, 12, 229-232. [CrossRef]

81. Kwon, S.; Lee, S. Instantaneous microwave imaging with time-domain measurements for breast cancer detection. Electron. Lett. 2013, 49, 639-641. [CrossRef]

82. Santorelli, A.; Porter, E.; Kang, E.; Piske, T.; Popović, M.; Schwartz, J.D. A time-domain microwave system for breast cancer detection using a flexible circuit board. IEEE Trans. Instrum. Meas. 2015, 64, 2986-2994. [CrossRef]

83. Porter, E.; Bahrami, H.; Santorelli, A.; Gosselin, B.; Rusch, L.A.; Popović, M. A Wearable Microwave Antenna Array for Time-Domain Breast Tumour Screening. IEEE Trans. Med. Imaging 2016, 35, 1501-1509. [CrossRef]

84. Li, Y.; Porter, E.; Santorelli, A.; Popović, M.; Coates, M. Microwave breast cancer detection via cost-sensitive ensemble classifiers: Phantom and patient investigation. Biomed. Signal Process. Control 2017, 31, 366-376. [CrossRef]

85. Zhang, Z.Q.; Liu, Q.H. Three-dimensional nonlinear image reconstruction for microwave biomedical imaging. IEEE Trans. Biomed. Eng. 2004, 51, 544-548. [CrossRef] [PubMed]

86. Bozza, G.; Brignone, M.; Pastorino, M. Application of the no-sampling linear sampling method to breast cancer detection. IEEE Trans. Biomed. Eng. 2010, 57, 2525-2534. [CrossRef]

87. Bellizzi, G.; Bucci, O.M.; Catapano, I. Microwave cancer imaging exploiting magnetic nanoparticles as contrast agent. IEEE Trans. Biomed. Eng. 2011, 58, 2528-2536. [CrossRef]

88. Bucci, O.; Bellizzi, G.; Catapano, I.; Crocco, L.; Scapaticci, R. MNP enhanced microwave breast cancer imaging: Measurement constraints and achievable performances. IEEE Antennas Wirel. Propag. Lett. 2012, 11, 1630-1633. [CrossRef]

89. Scapaticci, R.; Catapano, I.; Crocco, L. Wavelet-based adaptive multiresolution inversion for quantitative microwave imaging of breast tissues. IEEE Trans. Antennas Propag. 2012, 60, 3717-3726. [CrossRef]

90. Scapaticci, R.; Bellizzi, G.; Catapano, I.; Crocco, L.; Bucci, O.M. An effective procedure for MNP-enhanced breast cancer microwave imaging. IEEE Trans. Biomed. Eng. 2013, 61, 1071-1079. [CrossRef] [PubMed]

91. Baran, A.; Kurrant, D.J.; Zakaria, A.; Fear, E.C.; LoVetri, J. Breast imaging using microwave tomography with radar-based tissue-regions estimation. Prog. Electromagn. Res. 2014, 149, 161-171. [CrossRef]

92. Scapaticci, R.; Kosmas, P.; Crocco, L. Wavelet-based regularization for robust microwave imaging in medical applications. IEEE Trans. Biomed. Eng. 2014, 62, 1195-1202. [CrossRef]

93. Bevacqua, M.T.; Scapaticci, R. A compressive sensing approach for 3D breast cancer microwave imaging with magnetic nanoparticles as contrast agent. IEEE Trans. Med. Imaging 2015, 35, 665-673. [CrossRef]

94. Palmeri, R.; Bevacqua, M.; Scapaticci, R.; Morabito, A.; Crocco, L.; Isernia, T. Biomedical imaging via wavelet-based regularization and distorted iterated virtual experiments. In Proceedings of the 2017 International Conference on Electromagnetics in Advanced Applications (ICEAA), Verona, Italy, 11-15 September 2017; pp. 1381-1384.

95. Neira, L.M.; Van Veen, B.D.; Hagness, S.C. High-resolution microwave breast imaging using a 3-D inverse scattering algorithm with a variable-strength spatial prior constraint. IEEE Trans. Antennas Propag. 2017, 65, 6002-6014. [CrossRef]

96. Miao, Z.; Kosmas, P. Multiple-frequency DBIM-TwIST algorithm for microwave breast imaging. IEEE Trans. Antennas Propag. 2017, 65, 2507-2516. [CrossRef]

97. Ambrosanio, M.; Kosmas, P.; Pascazio, V. A Multithreshold Iterative DBIM-Based Algorithm for the Imaging of Heterogeneous Breast Tissues. IEEE Trans. Biomed. Eng. 2018, 66, 509-520. [CrossRef]

98. Bevacqua, M.T.; Palmeri, R.; Scapaticci, R. Multiresolution Virtual Experiments for Microwave Imaging of Complex Scenarios. Electronics 2019, 8, 153. [CrossRef]

99. Maffongelli, M.; Poretti, S.; Salvadè, A.; Monleone, R.D.; Meani, F.; Fedeli, A.; Pastorino, M.; Randazzo, A. Preliminary test of a prototype of microwave axial tomograph for medical applications. In Proceedings of the 2015 IEEE International Symposium on Medical Measurements and Applications (MeMeA) Proceedings, Torino, Italy, 7-9 May 2015; pp. 46-51. 
100. Bucci, O.M.; Bellizzi, G.; Borgia, A.; Costanzo, S.; Crocco, L.; Di Massa, G.; Scapaticci, R. Experimental framework for magnetic nanoparticles enhanced breast cancer microwave imaging. IEEE Access 2017, 5, 16332-16340. [CrossRef]

101. Maffongelli, M.; Poretti, S.; Salvadè, A.; Monleone, R.; Pagnamenta, C.; Fedeli, A.; Pastorino, M.; Randazzo, A. Design and experimental test of a microwave system for quantitative biomedical imaging. In Proceedings of the 2018 IEEE International Symposium on Medical Measurements and Applications (MeMeA), Rome, Italy, 11-13 June 2018; pp. 1-6.

102. Poplack, S.P.; Paulsen, K.D.; Hartov, A.; Meaney, P.M.; Pogue, B.W.; Tosteson, T.D.; Grove, M.R.; Soho, S.K.; Wells, W.A. Electromagnetic breast imaging: Average tissue property values in women with negative clinical findings. Radiology 2004, 231, 571-580. [CrossRef] [PubMed]

103. Poplack, S.P.; Tosteson, T.D.; Wells, W.A.; Pogue, B.W.; Meaney, P.M.; Hartov, A.; Kogel, C.A.; Soho, S.K.; Gibson, J.J.; Paulsen, K.D. Electromagnetic breast imaging: Results of a pilot study in women with abnormal mammograms. Radiology 2007, 243, 350-359. [CrossRef] [PubMed]

104. Meaney, P.M.; Fanning, M.W.; Raynolds, T.; Fox, C.J.; Fang, Q.; Kogel, C.A.; Poplack, S.P.; Paulsen, K.D. Initial clinical experience with microwave breast imaging in women with normal mammography. Acad. Radiol. 2007, 14, 207-218. [CrossRef]

105. Meaney, P.M.; Kaufman, P.A.; Muffly, L.S.; Click, M.; Poplack, S.P.; Wells, W.A.; Schwartz, G.N.; di Florio-Alexander, R.M.; Tosteson, T.D.; Li, Z.; et al. Microwave imaging for neoadjuvant chemotherapy monitoring: Initial clinical experience. Breast Cancer Res. 2013, 15, R35. [CrossRef]

106. Epstein, N.; Meaney, P.; Paulsen, K. 3D parallel-detection microwave tomography for clinical breast imaging. Rev. Sci. Instrum. 2014, 85, 124704. [CrossRef]

107. Lavoie, B.R.; Okoniewski, M.; Fear, E.C. Estimating the effective permittivity for reconstructing accurate microwave-radar images. PLoS ONE 2016, 11, e0160849. [CrossRef]

108. Curtis, C.; Lavoie, B.R.; Fear, E. An analysis of the assumptions inherent to near-field beamforming for biomedical applications. IEEE Trans. Comput. Imaging 2017, 3, 953-965. [CrossRef]

109. Kurrant, D.; Bourqui, J.; Fear, E. Surface estimation for microwave imaging. Sensors 2017, 17, 1658. [CrossRef]

110. Porter, E.; Coates, M.; Popović, M. An early clinical study of time-domain microwave radar for breast health monitoring. IEEE Trans. Biomed. Eng. 2016, 63, 530-539. [CrossRef]

111. Henriksson, T.; Klemm, M.; Gibbins, D.; Leendertz, J.; Horseman, T.; Preece, A.; Benjamin, R.; Craddock, I. Clinical trials of a multistatic UWB radar for breast imaging. In Proceedings of the November 2011 Loughborough Antennas \& Propagation Conference, Loughborough, UK, 14-15 November 2011; pp. 1-4.

112. Preece, A.W.; Craddock, I.; Shere, M.; Jones, L.; Winton, H.L. MARIA M4: Clinical evaluation of a prototype ultra-wideband radar scanner for breast cancer detection. J. Med. Imaging 2016, 3, 033502. [CrossRef]

113. Bannister, P. A novel microwave radar breast imaging system in a symptomatic breast clinic. In Proceedings of the BSBR Breast Imaging Research Network Workshop, Manchester, UK, 6 November 2016.

114. Ridley, N.; Shere, M.H.; Lyburn, I.; Bannister, P. Cancer detection in dense tissue using radiofrequency imaging-A clincial evaluation. In Proceedings of the European Congress of Radiology, Vienna, Austria, 1-5 March 2017.

115. Kuwahara, Y.; Miura, S.; Nishina, Y.; Mukumoto, K.; Ogura, H.; Sakahara, H. Clinical test of microwave mammography. In Proceedings of the 2013 IEEE Antennas and Propagation Society International Symposium (APSURSI), Buena Vista, FL, USA, 7-13 July 2013; pp. 2028-2029.

116. Kuwahara, Y. Microwave imaging for early breast cancer detection. In New Perspectives in Breast Imaging; Intechopen: London, UK, 2017; p. 45.

117. Yang, F.; Sun, L.; Hu, Z.; Wang, H.; Pan, D.; Wu, R.; Zhang, X.; Chen, Y.; Zhang, Q. A large-scale clinical trial of radar-based microwave breast imaging for Asian women: Phase I. In Proceedings of the 2017 IEEE International Symposium on Antennas and Propagation \& USNC/URSI National Radio Science Meeting, San Diego, CA, USA, 9-14 July 2017; pp. 781-783.

118. Song, H.; Sasada, S.; Kadoya, T.; Okada, M.; Arihiro, K.; Xiao, X.; Kikkawa, T. Detectability of breast tumour by a hand-held impulse-radar detector: Performance evaluation and pilot clinical study. Sci. Rep. 2017, 7, 16353. [CrossRef] [PubMed]

119. Rana, S.P.; Dey, M.; Tiberi, G.; Sani, L.; Vispa, A.; Raspa, G.; Duranti, M.; Ghavami, M.; Dudley, S. Machine Learning Approaches for Automated Lesion Detection in Microwave Breast Imaging Clinical Data. Sci. Rep. 2019, 9, 10510. [CrossRef] 
120. Hagness, S.C.; Taflove, A.; Bridges, J.E. FDTD analysis of a pulsed microwave confocal system for breast cancer detection. In Proceedings of the 19th Annual International Conference of the IEEE Engineering in Medicine and Biology Society, Chicago, IL, USA, 30 October-2 November 1997; Volume 6, pp. 2506-2508.

121. PopoviC, M.; Hagness, S.C.; Taflove, A.; Bridges, J. 2-D FDTD study of fixed-focus elliptical reflector system for breast cancer detection: Frequency window for optimum operation. In Proceedings of the IEEE Antennas and Propagation Society International Symposium, Atlanta, GA, USA, 21-26 June 1998; Volume 4, pp. 1992-1995.

122. Fear, E.C.; Stuchly, M.A. Microwave system for breast tumour detection. IEEE Microw. Guided Wave Lett. 1999, 9, 470-472. [CrossRef]

123. Hagness, S.C.; Taflove, A.; Bridges, J.E. Three-dimensional FDTD analysis of a pulsed microwave confocal system for breast cancer detection: Design of an antenna-array element. IEEE Trans. Antennas Propag. 1999, 47, 783-791. [CrossRef]

124. Fear, E.; Stuchly, M. Microwave detection of breast cancer: A study of tumour response variations. In Proceedings of the 22nd Annual International Conference of the IEEE Engineering in Medicine and Biology Society, Chicago, IL, USA, 23-28 July 2000; Volume 1, pp. 74-77.

125. Fear, E.; Stuchly, M. Confocal microwave imaging for breast tumour detection: Comparison of immersion liquids. In Proceedings of the IEEE Antennas and Propagation Society International Symposium, Boston, MA, USA, 8-13 July 2001; Volume 1, pp. 250-253.

126. Davis, S.K.; Li, X.; Bond, E.J.; Hagness, S.C.; Van Veen, B.D. Frequency-domain penalized least-squares beamformer design for early detection of breast cancer via microwave imaging. In Proceedings of the IEEE Sensor Array and Multichannel Signal Processing Workshop Proceedings, Rosslyn, VA,USA, 6 August 2002; pp. 120-124.

127. Fear, E.C.; Sill, J.; Stuchly, M.A. Experimental feasibility study of confocal microwave imaging for breast tumour detection. IEEE Trans. Microw. Theory Tech. 2003, 51, 887-892. [CrossRef]

128. Bond, E.J.; Li, X.; Hagness, S.C.; Van Veen, B.D. Microwave imaging via space-time beamforming for early detection of breast cancer. IEEE Trans. Antennas Propag. 2003, 51, 1690-1705. [CrossRef]

129. Nilavalan, R.; Gbedemah, A.; Craddock, I.; Li, X.; Hagness, S.C. Numerical investigation of breast tumour detection using multi-static radar. Electron. Lett. 2003, 39, 1787-1789 . [CrossRef]

130. Shannon, C.; Okoniewski, M.; Fear, E. A dielectric filled ultra-wideband antenna for breast cancer detection. In Proceedings of the IEEE Antennas and Propagation Society International Symposium, Columbus, $\mathrm{OH}$, USA, 22-27 June 2003; Volume 1, pp. 218-221.

131. Davis, S.K.; Bond, E.J.; Hagness, S.; Van Veen, B. Microwave imaging via space-time beamforming for early detection of breast cancer: Beamformer design in the frequency domain. J. Electromagn. Waves Appl. 2003, 17, 357-381. [CrossRef]

132. Oral, E.; Sahakian, A. 3-D microwave imaging of breast tumours with matched-filtering. In Proceedings of the 26th Annual International Conference of the IEEE Engineering in Medicine and Biology Society (IEMBS'04), Francisco, CA, USA, 1-5 September 2004; Volume 1, pp. 1423-1426.

133. Zhao, Y.; Shao, W.; Wang, G. UWB microwave imaging for early breast cancer detection: Effect of two synthetic antenna array configurations. In Proceedings of the 2004 IEEE International Conference on Systems, Man and Cybernetics, The Hague, The Netherlands, 10-13 October 2004; Volume 5, pp. 4468-4473.

134. Kosmas, P.; Rappaport, C.M.; Bishop, E. Modeling with the FDTD method for microwave breast cancer detection. IEEE Trans. Microw. Theory Tech. 2004, 52, 1890-1897. [CrossRef]

135. Li, X.; Davis, S.K.; Hagness, S.C.; Van der Weide, D.W.; Van Veen, B.D. Microwave imaging via space-time beamforming: Experimental investigation of tumour detection in multilayer breast phantoms. IEEE Trans. Microw. Theory Tech. 2004, 52, 1856-1865. [CrossRef]

136. Nilavalan, R.; Leendertz, J.; Craddock, I.; Preece, A.; Benjamin, R. Numerical analysis of microwave detection of breast tumours using synthetic focussing techniques. In Proceedings of the IEEE Antennas and Propagation Society International Symposium, Monterey, CA, USA, 20-25 June 2004; Volume 3, pp. 2440-2443.

137. Davis, S.K.; Tandradinata, H.; Hagness, S.C.; Van Veen, B.D. Ultrawideband microwave breast cancer detection: A detection-theoretic approach using the generalized likelihood ratio test. IEEE Trans. Biomed. Eng. 2005, 52, 1237-1250. [CrossRef] [PubMed] 
138. Kosmas, P.; Rappaport, C.M. Time reversal with the FDTD method for microwave breast cancer detection. IEEE Trans. Microw. Theory Tech. 2005, 53, 2317-2323. [CrossRef]

139. Craddock, I.; Nilavalan, R.; Leendertz, J.; Preece, A.; Benjamin, R. Experimental investigation of real aperture synthetically organised radar for breast cancer detection. In Proceedings of the IEEE Antennas and Propagation Society International Symposium, Washington, DC, USA, 3-8 July 2005; Volume 1, pp. 179-182.

140. Guo, B.; Wang, Y.; Li, J.; Stoica, P.; Wu, R. Microwave imaging via adaptive beamforming methods for breast cancer detection. PIERS Online 2005, 1, 350-353. [CrossRef]

141. Li, X.; Bond, E.J.; Van Veen, B.D.; Hagness, S.C. An overview of ultra-wideband microwave imaging via space-time beamforming for early-stage breast-cancer detection. IEEE Antennas Propag. Mag. 2005, 47, $19-34$.

142. Sill, J.; Fear, E. Tissue sensing adaptive radar for breast cancer detection: Study of immersion liquids. Electron. Lett. 2005, 41, 113-115. [CrossRef]

143. Nilavalan, R.; Leendertz, J.; Craddock, I.; Benjamin, R.; Preece, A. Breast Tumour Detection Using a Flat 16 Element Array; EMC: Zurich, Switzerland, 2005.

144. Sill, J.M.; Fear, E.C. Tissue sensing adaptive radar for breast cancer detection-Experimental investigation of simple tumour models. IEEE Trans. Microw. Theory Tech. 2005, 53, 3312-3319. [CrossRef]

145. Baang, S.; Lee, Y.U.; Park, C.Y.; Kim, J.D. Signal Modeling with Random Scatterers for Confocal Microwave Imaging. In Proceedings of the 27th Annual International Conference of the Engineering in Medicine and Biology Society (IEEE-EMBS), Shanghai, China, 17-18 January 2006; pp. 1622-1625.

146. Bindu, G.; Abraham, S.J.; Lonappan, A.; Thomas, V.; Aanandan, C.; Mathew, K. Detection of dielectric contrast of breast tissues using confocal microwave technique. Microw. Opt. Technol. Lett. 2006, 48, 1187-1190. [CrossRef]

147. Shao, W.; Zhou, B.; Zheng, Z.; Wang, G. UWB microwave imaging for breast tumour detection in inhomogeneous tissue. In Proceedings of the 27th Annual International Conference of the Engineering in Medicine and Biology Society (IEEE-EMBS), Shanghai, China, 17-18 January 2006; pp. 1496-1499.

148. Xie, Y.; Guo, B.; Li, J.; Stoica, P. Novel multistatic adaptive microwave imaging methods for early breast cancer detection. EURASIP J. Appl. Signal Process. 2006, 2006, 091961. [CrossRef]

149. Bond, E.J.; Van Veen, B.D.; Hagness, S.C. Multiple window based ultra-wideband microwave imaging for early-stage breast cancer detection. In Proceedings of the 2006 Fourth IEEE Workshop on Sensor Array and Multichannel Processing, Waltham, MA, USA, 12-14 July 2006; pp. 127-131.

150. Chen, Y.; Gunawan, E.; Kim, Y.; Low, K.S.; Soh, C.B.; Thi, L.L. UWB microwave breast cancer detection: Generalized models and performance prediction. In Proceedings of the 2006 28th Annual International Conference of the IEEE Engineering in Medicine and Biology Society (EMBS'06), New York, NY, USA, 30 August-3 September 2006; pp. 2630-2633.

151. Craddock, I.; Preece, A.; Leendertz, J.; Klemm, M.; Nilavalan, R.; Benjamin, R. Development of a hemispherical wideband antenna array for breast cancer imaging. In Proceedings of the 2006 First European Conference on Antennas and Propagation, Nice, France, 6-11 November 2006; pp. 1-5.

152. Kosmas, P.; Rappaport, C.M. A matched-filter FDTD-based time reversal approach for microwave breast cancer detection. IEEE Trans. Antennas Propag. 2006, 54, 1257-1264. [CrossRef]

153. Liu, W.; Jafari, H.; Hranilovic, S.; Deen, M. Time domain analysis of UWB breast cancer detection. In Proceedings of the 2006 23rd Biennial Symposium on Communications, Kigston, ON, Canada, 29 May-1 June 2006; pp. 336-339.

154. Xie, Y.; Guo, B.; Xu, L.; Li, J.; Stoica, P. Multistatic adaptive microwave imaging for early breast cancer detection. IEEE Trans. Biomed. Eng. 2006, 53, 1647-1657. [CrossRef]

155. Kosmas, P.; Rappaport, C.M. FDTD-based time reversal for microwave breast cancer detection-localization in three dimensions. IEEE Trans. Microw. Theory Tech. 2006, 54, 1921-1927. [CrossRef]

156. Zhi, W.; Chin, F. Entropy-based time window for artifact removal in UWB imaging of breast cancer detection. IEEE Signal Process. Lett. 2006, 13, 585-588. [CrossRef]

157. Xiao, X.; Kubota, S.; Kikkawa, T. A method for quasi 3-dimensional imaging for early breast cancer detection by UWB. In Proceedings of the IEEE International Conference on Ultra-Wideband (ICUWB), Singapore, 24-26 September 2007; pp. 596-599.

158. Ryu, S.W.; Kishk, A.A. Adaptive Tuning Amplitude and Phase Estimation Method for Early Breast Cancer Detection. In Proceedings of the 2007 IEEE Region 5 Technical Conference, Fayetteville, AR, USA, 20-22 April 2007; pp. 16-20. 
159. Tayel, M.; Ismail, N.E.D.H.; Ramadan, H.D. Confocal Microwave Imaging for Breast Cancer Detection Via Adaptive Beamforming. In Proceedings of the Radio Science Conference (NRSC), Cairo, Egypt, 13-15 March 2007; pp. 1-11.

160. Xiao, X.; Kikkawa, T. Extraction of calibration waveform for confocal microwave imaging for early breast cancer detection. In Proceedings of the 2007 International Symposium on Microwave, Antenna, Propagation and EMC Technologies for Wireless Communications, Hangzhou, China, 16-17 August 2007; pp. 1287-1290.

161. Chen, Y.; Gunawan, E.; Low, K.S.; Wang, S.C.; Kim, Y.; Soh, C.B. Pulse design for time reversal method as applied to ultra-wideband microwave breast cancer detection: A two-dimensional analysis. IEEE Trans. Antennas Propag. 2007, 55, 194-204. [CrossRef]

162. Abedin, M.J.; Mohan, A.S. UWB imaging for early breast cancer detection using time reversal MUSIC algorithm. In Proceedings of the Asia-Pacific Microwave Conference (APMC), Bangkok, Thailand, 11-14 December 2007; pp. 1-4.

163. Elsdon, M.; Leach, M.; Skobelev, S.; Smith, D. Microwave holographic imaging of breast cancer. In Proceedings of the 2007 International Symposium on Microwave, Antenna, Propagation and EMC Technologies for Wireless Communications, Hangzhou, China, 16-17 August 2007; pp. 966-969.

164. Jafari, H.; Deen, J.; Hranilovic, S.; Nikolova, N. Co-polarised and cross-polarised antenna arrays for breast, cancer detection. IET Microw. Antennas Propag. 2007, 1, 1055-1058. [CrossRef]

165. Jin, Y.; Jiang, Y.; Moura, J.M. Time reversal beamforming for microwave breast cancer detection. In Proceedings of the IEEE International Conference on Image Processing (ICIP), San Antonio, TX, USA, 16 September-19 October 2007.

166. Klemm, M.; Craddock, I.; Leendertz, J.; Preece, A.; Benjamin, R. Breast cancer detection using symmetrical antenna array. In Proceedings of the Second European Conference on Antennas and Propagation (EuCAP), Edinburgh, UK, 11-16 November 2007; pp. 1-5.

167. Zhuge, X.; Hajian, M.; Yarovoy, A.; Ligthart, L. Ultra-wideband imaging for detection of early-stage breast cancer. In Proceedings of the European Radar Conference (EuRAD), Munich, Germany, 10-12 October 2007; pp. $39-42$.

168. Lim, H.B.; Nhung, N.T.T.; Li, E.P.; Thang, N.D. Confocal microwave imaging for breast cancer detection: Delay-multiply-and-sum image reconstruction algorithm. IEEE Trans. Biomed. Eng. 2008, 55, 1697-1704. [PubMed]

169. Craddock, I.; Klemm, M.; Leendertz, J.; Preece, A.; Benjamin, R. Development and application of a UWB radar system for breast imaging. In Proceedings of the Loughborough Antennas and Propagation Conference (LAPC), Loughborough, UK, 17-18 March 2008; pp. 24-27.

170. Kubota, S.; Xiao, X.; Sasaki, N.; Kimoto, K.; Moriyama, W.; Kikkawa, T. Experimental confocal imaging for breast cancer detection using silicon on-chip UWB microantenna array. In Proceedings of the 2008 IEEE Antennas and Propagation Society International Symposium (AP-S), San Diego, CA, USA, 5-11 July 2008; pp. 1-4.

171. Xiao, X.; Kikkawa, T. Study on the breast cancer detection by UWB microwave imaging. In Proceedings of the IEEE International Conference on Microwave and Millimeter Wave Technology (ICMMT), Nanjing, China, 21-24 April 2008; Volume 4, pp. 1707-1710.

172. Takaichi, S.; Mase, A.; Kogi, Y.; Hojo, H.; Kim, K.W. Simulation study and experiment of breast cancer detection using an ultrashort-pulse radar. In Proceedings of the IEEE Asia-Pacific Microwave Conference (APMC), Macau, China, 16-20 December 2008; pp. 1-4.

173. Xiao, X.; Kikkawa, T. Influence of the organism interface on the breast cancer detection by UWB. Appl. Surf. Sci. 2008, 255, 597-599. [CrossRef]

174. Klemm, M.; Craddock, I.; Leendertz, J.; Preece, A.; Benjamin, R. Improved delay-and-sum beamforming algorithm for breast cancer detection. Int. J. Antennas Propag. 2008, 2008, 761402. [CrossRef]

175. Chen, Y.; Gunawan, E.; Low, K.S.; Wang, S.c.; Soh, C.B.; Putti, T.C. Time-reversal ultra-wideband breast imaging: Pulse design criteria considering multiple tumours with unknown tissue properties. IEEE Trans. Antennas Propag. 2008, 56, 3073-3077. [CrossRef]

176. Davis, S.K.; Van Veen, B.D.; Hagness, S.C.; Kelcz, F. Breast tumour characterization based on ultra-wideband microwave backscatter. IEEE Trans. Biomed. Eng. 2008, 55, 237-246. [CrossRef] 
177. Jin, Y.; Moura, J.M.; Jiang, Y.; Wahl, M.; Zhu, H.; He, Q. Breast cancer detection by time reversal imaging. In Proceedings of the 5th IEEE International Symposium on Biomedical Imaging: From Nano to Macro (ISBI), Paris, France, 14-17 May 2008; pp. 816-819.

178. Chen, Y.; Gunawan, E.; Low, K.S.; Wang, S.C.; Soh, C.B.; Putti, T.C. Effect of lesion morphology on microwave signature in 2-D ultra-wideband breast imaging. IEEE Trans. Biomed. Eng. 2008, 55, 2011-2021. [CrossRef]

179. Klemm, M.; Craddock, I.; Preece, A.; Leendertz, J.; Benjamin, R. Evaluation of a hemi-spherical wideband antenna array for breast cancer imaging. Radio Sci. 2008, 43. [CrossRef]

180. Winters, D.W.; Shea, J.D.; Madsen, E.L.; Frank, G.R.; Van Veen, B.D.; Hagness, S.C. Estimating the breast surface using UWB microwave monostatic backscatter measurements. IEEE Trans. Biomed. Eng. 2008, 55, 247-256. [CrossRef] [PubMed]

181. Yu, C.; Yuan, M.; Stang, J.; Bresslour, E.; George, R.T.; Ybarra, G.A.; Joines, W.T.; Liu, Q.H. Active microwave imaging II: 3-D system prototype and image reconstruction from experimental data. IEEE Trans. Microw. Theory Tech. 2008, 56, 991-1000.

182. Byrne, D.; O'Halloran, M.; Jones, E.; Glavin, M. A comparison of data-independent microwave beamforming algorithms for the early detection of breast cancer. In Proceedings of the Annual International Conference of the IEEE Engineering in Medicine and Biology Society (EMBC), Minneapolis, MN, USA, 3-6 September 2009; pp. 2731-2734.

183. Kouzaki, T.; Kimoto, K.; Kubota, S.; Toya, A.; Sasaki, N.; Kikkawa, T. Quasi Yagi-Uda antenna array for detecting targets in a dielectric substrate. In Proceedings of the IEEE International Conference on Ultra-Wideband (ICUWB), Vancouver, BC, Canada, 9-11 September 2009; pp. 759-762.

184. Liu, X.; Xiao, X.; Fan, Z.; Yu, J. Study on the imaging resolution of ultra-wideband microwave imaging for breast cancer detection. In Proceedings of the 3rd International Conference on Bioinformatics and Biomedical Engineering (ICBBE), Beijing, China, 11-13 June 2009; pp. 1-4.

185. Xiao, X.; Kikkawa, T. Early breast cancer detection with hemi-elliptical configuration by UWB imaging. In Proceedings of the 3rd International Conference on Bioinformatics and Biomedical Engineering (ICBBE), Beijing, China, 11-13 June 2009; pp. 1-4.

186. Yang, F; Mohan, A.S. Detection of malignant breast tissues using microwave imaging. In Proceedings of the IEEE Asia Pacific Microwave Conference (APMC), Singapore, 7-10 December 2009; pp. 397-400.

187. Johnson, J.E.; Takenaka, T.; Ping, K.A.H.; Honda, S.; Tanaka, T. Advances in the 3-D forward-backward time-stepping (FBTS) inverse scattering technique for breast cancer detection. IEEE Trans. Biomed. Eng. 2009, 56, 2232-2243. [CrossRef] [PubMed]

188. Khor, W.C.; Bakar, A.A.; Bialkowski, M.E. Investigations into breast cancer detection using ultra wide band microwave radar technique. In Proceedings of the IEEEAsia Pacific Microwave Conference (APMC), Singapore, 7-10 December 2009; pp. 712-715.

189. Klemm, M.; Craddock, I.J.; Leendertz, J.A.; Preece, A.; Benjamin, R. Radar-based breast cancer detection using a hemispherical antenna array-Experimental results. IEEE Trans. Antennas Propag. 2009, 57, 1692-1704. [CrossRef]

190. Kurrant, D.J.; Fear, E.C. An improved technique to predict the time-of-arrival of a tumour response in radar-based breast imaging. IEEE Trans. Biomed. Eng. 2009, 56, 1200-1208. [CrossRef]

191. Yao, M.; Pan, Q.f.; Tao, Z.f. Application of quantum genetic algorithm on breast tumour imaging with microwave. In Proceedings of the 11th Annual Conference Companion on Genetic and Evolutionary Computation Conference, Montréal, QC, Canada, 8-12 July 2009; pp. 2685-2688.

192. Sajjadieh, M.; Foroozan, F.; Asif, A. Breast cancer detection using time reversal signal processing. In Proceedings of the IEEE 13th International Multitopic Conference (INMIC), Islamabad, Pakistan, 14-15 December 2009; pp. 1-5.

193. Kubota, S.; Xiao, X.; Sasaki, N.; Kayaba, Y.; Kimoto, K.; Moriyama, W.; Kozaki, T.; Hanada, M.; Kikkawa, T. Confocal imaging using ultra wideband antenna array on Si substrates for breast cancer detection. Jpn. J. Appl. Phys. 2010, 49, 097001. [CrossRef]

194. Shao, W.; Adams, R.S. UWB imaging with multi-polarized signals for early breast. In Proceedings of the 2010 IEEE Antennas and Propagation Society International Symposium (APSURSI), Toronto, ON, Canada, 11-17 July 2010; pp. 1-4.

195. Byrne, D.; O’Halloran, M.; Glavin, M.; Jones, E. Data independent radar beamforming algorithms for breast cancer detection. Prog. Electromagn. Res. 2010, 107, 331-348. [CrossRef] 
196. Deprez, J.F.; Klemm, M.; Smith, P.P.; Craddock, I. Twin target correction for ultra-wideband radar imaging of breast tumours. In Proceedings of the 2010 IEEE International Symposium on Biomedical Imaging: From Nano to Macro, Rotterdam, The Netherlands, 14-17 April 2010; pp. 213-216.

197. Byrne, D.; O’Halloran, M.; Jones, E.; Glavin, M. Transmitter-grouping robust capon beamforming for breast cancer detection. Prog. Electromagn. Res. 2010, 108, 401-416. [CrossRef]

198. O'Halloran, M.; Jones, E.; Glavin, M. Quasi-multistatic MIST beamforming for the early detection of breast cancer. IEEE Trans. Biomed. Eng. 2010, 57, 830-840. [CrossRef]

199. Klemm, M.; Leendertz, J.; Gibbins, D.; Craddock, I.; Preece, A.; Benjamin, R. Towards contrast enhanced breast imaging using ultra-wideband microwave radar system. In Proceedings of the 2010 IEEE Radio and Wireless Symposium (RWS), New Orleans, LA, USA, 10-14 January 2010; pp. 516-519.

200. Sarafianou, M.; Gibbins, D.; Craddock, I.; Klemm, M.; Leendertz, J.; Preece, A.; Benjamin, R. Breast surface reconstruction algorithm for a multi-static radar-based breast imaging system. In Proceedings of the 2010 Proceedings of the Fourth European Conference on Antennas and Propagation (EuCAP), Barcelona, Spain, 12-16 April 2010; pp. 1-5.

201. Klemm, M.; Leendertz, J.A.; Gibbins, D.; Craddock, I.J.; Preece, A.; Benjamin, R. Microwave radar-based differential breast cancer imaging: Imaging in homogeneous breast phantoms and low contrast scenarios. IEEE Trans. Antennas Propag. 2010, 58, 2337-2344. [CrossRef]

202. Shea, J.; Kosmas, P.; Van Veen, B.; Hagness, S. Contrast-enhanced microwave imaging of breast tumours: A computational study using 3D realistic numerical phantoms. Inverse Probl. 2010, 26, 074009. [CrossRef] [PubMed]

203. Teo, J.; Chen, Y.; Soh, C.B.; Gunawan, E.; Low, K.S.; Putti, T.C.; Wang, S.C. Breast lesion classification using ultra-wideband early time breast lesion response. IEEE Trans. Antennas Propag. 2010, 58, 2604-2613. [CrossRef]

204. Bialkowski, M.; Abbosh, A.; Wang, Y.; Ireland, D.; Bakar, A.A.; Mohammed, B. Microwave imaging systems employing cylindrical, hemispherical and planar arrays of ultra-wideband antennas. In Proceedings of the 2011 Asia-Pacific Microwave Conference Proceedings (APMC), Melbourne, VIC, USA, 5-8 December 2011; pp. 191-194.

205. O'Halloran, M.; Glavin, M.; Jones, E. Improved Confocal Microwave Imaging of the breast using path-dependent signal weighting. In Proceedings of the 2011 URSI General Assembly and Scientific Symposium, Istanbul, Turkey, 13-20 August 2011; pp. 1-4.

206. Liu, B.; Xiao, X.; Liu, X. Ultra-wideband microwave image reconstruction by robust capon beamforming algorithm for early breast cancer detection. In Proceedings of the 2011 International Conference on Control, Automation and Systems Engineering (CASE), Singapore, 30-31 July 2011; pp. 1-4.

207. Shao, W.; Adams, R.S. UWB microwave imaging for early breast cancer detection: A novel confocal imaging algorithm. In Proceedings of the 2011 IEEE International Symposium on Antennas and Propagation (APSURSI), Spokane, WA, USA, 3-8 July 2011; pp. 707-709.

208. Zhang, D.; Mase, A. Radar-based breast cancer detection experiment with synthetic breast phantom using model subtraction method. In Proceedings of the 2011 Asia-Pacific Microwave Conference Proceedings (APMC), Melbourne, VIC, USA, 5-8 December 2011; pp. 207-210.

209. Donelli, M.; Craddock, I.J.; Gibbins, D.; Sarafianou, M. A three-dimensional time domain microwave imaging method for breast cancer detection based on an evolutionary algorithm. Prog. Electromagn. Res. M 2011, 18, 179-195. [CrossRef]

210. Fumeaux, C.; Klemm, M.; Baumann, D. Large-scale transient simulations of breast cancer tumour's reflections using a 31-element conformal array. In Proceedings of the 2011 Asia-Pacific Microwave Conference Proceedings (APMC), Melbourne, VIC, USA, 5-8 December 2011; pp. 1993-1996.

211. Golnabi, A.H.; Meaney, P.M.; Epstein, N.R.; Paulsen, K.D. Microwave imaging for breast cancer detection: Advances in three-Dimensional image reconstruction. In Proceedings of the 2011 Annual International Conference of the IEEE Engineering in Medicine and Biology Society (EMBC), Boston, MA, USA, 30 August-3 September 2011; pp. 5730-5733.

212. Klemm, M.; Gibbins, D.; Leendertz, J.; Horseman, T.; Preece, A.; Benjamin, R.; Craddock, I. Development and testing of a 60-element UWB conformal array for breast cancer imaging. In Proceedings of the 5th European Conference on Antennas and Propagation (EUCAP), Rome, Italy, 11-15 April 2011; pp. 3077-3079. 
213. Sajjadieh, M.H.; Asif, A. Unsupervised time reversal based microwave imaging for breast cancer detection. In Proceedings of the 2011 24th Canadian Conference on Electrical and Computer Engineering (CCECE), Niagara Falls, ON, Canada, 8-11 May 2011; pp. 001411-001415.

214. Sarafianou, M.; Gibbins, D.; Craddock, I. A novel 3-D breast surface reconstruction algorithm for a multi-static radar-based breast imaging system. In Proceedings of the 2011 Loughborough Antennas and Propagation Conference (LAPC), Loughborough, UK, 14-15 November 2011; pp. 1-4.

215. Zanoon, T.; Abdullah, M. Early stage breast cancer detection by means of time-domain ultra-wide band sensing. Meas. Sci. Technol. 2011, 22, 114016. [CrossRef]

216. Zeng, X.; Fhager, A.; Persson, M.; Linner, P.; Zirath, H. Accuracy evaluation of ultra-wideband time domain systems for microwave imaging. IEEE Trans. Antennas Propag. 2011, 59, 4279-4285. [CrossRef]

217. Padhi, S.; Mase, A.; Ito, N.; Zhang, D. Experimental performance of compact UWB antenna for breast cancer screening. In Proceedings of the 2012 International Conference on Electromagnetics in Advanced Applications (ICEAA), Cape Town, South Africa, 2-7 September 2012; pp. 490-493.

218. Shaheen, A.M.A.; Quboa, K.M. Breast cancer detection using UWB-confocal imaging techniques with halved averaging algorithm. In Proceedings of the 2012 20th IEEE Telecommunications Forum (TELFOR), Belgrade, Serbia, 20-22 November 2012; pp. 635-638.

219. Wang, Y.; Abbosh, A.; Henin, B. Microwave breast imaging sensor using compact and directive antenna with fixed mainbeam direction. In Proceedings of the 2012 Cairo International IEEE Biomedical Engineering Conference (CIBEC), Giza, Egypt, 20-22 December 2012; pp. 187-190.

220. Donelli, M.; Craddock, I.; Gibbins, D.; Sarafianou, M. Modelling complex electromagnetic sources for microwave imaging systems with wave field synthesis technique. Electron. Lett. 2012, 48, 1478-1479. [CrossRef]

221. Hossain, M.D.; Mohan, A.S. Breast cancer localization in three dimensions using time reversal DORT method. In Proceedings of the 2012 International Symposium on Antennas and Propagation (ISAP), Nagoys, Japan, 29 October-2 November 2012; pp. 471-474.

222. Deng, L.W.; Yuanjin, Z.; Zhiping, L.; Shengxi, D.; Yuan, G. MIMO ultra-wideband system for breast cancer detection. In Proceedings of the 2012 IEEE International Symposium on Radio-Frequency Integration Technology (RFIT), Singapore, 21-23 Novembe 2012; pp. 143-146.

223. Mohan, A.S.; Hossain, M.D.; Abedin, M.J. Beamspace based time reversal processing for breast cancer detection. In Proceedings of the 2012 IEEE Antennas and Propagation Society International Symposium (APSURSI), Chicago, IL, USA, 8-14 July 2012; pp. 1-2.

224. Shahzad, A.; O'halloran, M.; Jones, E.; Glavin, M. Prefiltered beamforming for early-stage breast cancer detection. IEEE Antennas Wirel. Propag. Lett. 2013, 12, 500-503. [CrossRef]

225. Sugitani, T.; Kubota, S.; Toya, A.; Xiao, X.; Kikkawa, T. A Compact $4 \times 4$ Planar UWB Antenna Array for 3-D Breast Cancer Detection. IEEE Antennas Wirel. Propag. Lett. 2013, 12, 733-736. [CrossRef]

226. Xu, L.; Xiao, X.; Kikkawa, T. Ultra-wide band microwave image reconstruction for early breast cancer detection by norm constrained capon beamforming. Math. Comput. Model. 2013, 58, 403-408. [CrossRef]

227. Sugitani, T.; Kubota, S.; Hafiz, M.; Toya, A.; Kikkawa, T. A breast cancer detection system using 198 ps Gaussian monocycle pulse CMOS transmitter and UWB antenna array. In Proceedings of the 2013 URSI International Symposium on Electromagnetic Theory (EMTS), Hiroshima, Japan, 20-24 May 2013; pp. 372-375.

228. Bassi, M.; Caruso, M.; Khan, M.S.; Bevilacqua, A.; Capobianco, A.D.; Neviani, A. An integrated microwave imaging radar with planar antennas for breast cancer detection. IEEE Trans. Microw. Theory Tech. 2013, 61, 2108-2118. [CrossRef]

229. Hossain, M.D.; Mohan, A.S.; Abedin, M.J. Beamspace time-reversal microwave imaging for breast cancer detection. IEEE Antennas Wirel. Propag. Lett. 2013, 12, 241-244. [CrossRef]

230. Kurrant, D.; Fear, E. Defining regions of interest for microwave imaging using near-field reflection data. IEEE Trans. Microw. Theory Tech. 2013, 61, 2137-2145. [CrossRef]

231. Ruvio, G.; Solimene, R.; D'Alterio, A.; Ammann, M.J.; Pierri, R. RF breast cancer detection employing a noncharacterized vivaldi antenna and a MUSIC-inspired algorithm. Int. J. RF Microw. Comput.-Aided Eng. 2013, 23, 598-609. [CrossRef]

232. Sarafianou, M.; Craddock, I.; Henriksson, T.; Klemm, M.; Gibbins, D.; Preece, A.; Leendertz, J.; Benjamin, R. MUSIC processing for permittivity estimation in a Delay-and-Sum imaging system. In Proceedings of the 2013 7th European Conference on Antennas and Propagation (EuCAP), Gothenburg, Sweden, 8-12 April 2013; pp. 839-842. 
233. Sarafianou, M.; Craddock, I.J.; Henriksson, T. Towards enhancing skin reflection removal and image focusing using a 3-D breast surface reconstruction algorithm. IEEE Trans. Antennas Propag. 2013, 61, 5343-5346. [CrossRef]

234. Xia, X.; Li, X.; Qin-Wei, L. A double constrained robust capon beamforming based imaging method for early breast cancer detection. Chin. Phys. B 2013, 22, 094101. [CrossRef]

235. Elahi, M.; Shahzad, A.; Glavin, M.; Jones, E.; O’halloran, M. Hybrid artifact removal for confocal microwave breast imaging. IEEE Antennas Wirel. Propag. Lett. 2014, 13, 149-152. [CrossRef]

236. Kikkawa, T.; Toya, A.; Xiao, X. CMOS equivalent time sampling circuit for breast cancer detection. In Proceedings of the 2014 12th IEEE International Conference on Solid-State and Integrated Circuit Technology (ICSICT), Guilin, China, 28-30 October 2014; pp. 1-4.

237. Sugitani, T.; Kubota, S.; Hafiz, M.; Xiao, X.; Kikkawa, T. Three-dimensional confocal imaging for breast cancer detection using CMOS Gaussian monocycle pulse transmitter and $4 \times 4$ ultra wideband antenna array with impedance matching layer. Jpn. J. Appl. Phys. 2014, 53, 04EL03. [CrossRef]

238. Bahrami, H.; Porter, E.; Santorelli, A.; Gosselin, B.; Popovic, M.; Rusch, L. Flexible sixteen monopole antenna array for microwave breast cancer detection. In Proceedings of the 2014 36th Annual International Conference of the IEEE Engineering in Medicine and Biology Society (EMBC), Chicago, IL, USA, 26-30 August 2014; pp. 3775-3778.

239. Moll, J.; Kelly, T.N.; Byrne, D.; Sarafianou, M.; Krozer, V.; Craddock, I.J. Microwave radar imaging of heterogeneous breast tissue integrating a priori information. J. Biomed. Imaging 2014, 2014, 943549. [CrossRef]

240. Ünal, İ.; Türetken, B.; Canbay, C. Spherical Conformal Bow-Tie Antenna for Ultra-Wide Band Microwave Imaging of Breast Cancer Tumour. Appl. Comput. Electromagn. Soc. J. 2014, 29.

241. Jalilvand, M.; Li, X.; Zwirello, L.; Zwick, T. Ultra wideband compact near-field imaging system for breast cancer detection. IET Microw. Antennas Propag. July 2015, 9, 1009-1014. [CrossRef]

242. Kikkawa, T.; Azhari, A.; Hashimoto, K.; Seo, Y.; Kohno, H.; Wang, M.; Xiao, X.; Toya, A.; Masui, Y.; Somei, J.; et al. Digital confocal imaging of breast cancer using UWB-CMOS integrated circuits. In Proceedings of the 2015 9th European Conference on Antennas and Propagation (EuCAP), Lisbon, Portugal, 12-17 April 2015; pp. 1-4.

243. Kono, H.; Sugitani, T.; Xiao, X.; Aritome, K.; Miyake, R.; Kikkawa, T. Confocal imaging of breast tumour phantom using 3-D-printed breast phantom. In Proceedings of the 2015 IEEE International Symposium on Antennas and Propagation \& USNC/URSI National Radio Science Meeting, Vancouver, BC, Canada, 19-24 July 2015; pp. 530-531.

244. Song, H.; Kono, H.; Seo, Y.; Azhari, A.; Somei, J.; Suematsu, E.; Watarai, Y.; Ota, T.; Watanabe, H.; Hiramatsu, Y.; et al. A radar-based breast cancer detection system using CMOS integrated circuits. IEEE Access 2015, 3, 2111-2121. [CrossRef]

245. Xiao, X.; Li, Q.; Wang, L. Early breast cancer detection via UWB based on MRI-derived model. In Proceedings of the 2015 Asia-Pacific Microwave Conference (APMC), Nanjing, China, 6-9 December 2015; Volume 2, p. 1.

246. Song, H.; Xiao, X.; Wang, Z.; Kikkawa, T. UWB microwave breast cancer detection with MRI-derived 3-D realistic numerical breast model. In Proceedings of the 2015 IEEE International Symposium on Antennas and Propagation \& USNC/URSI National Radio Science Meeting, Vancouver, BC, Canada, 19-24 July 2015; pp. 544-545.

247. Elahi, M.; Shahzad, A.; Glavin, M.; Jones, E.; O’Halloran, M. GPU accelerated confocal microwave imaging algorithms for breast cancer detection. In Proceedings of the 2015 9th European Conference on Antennas and Propagation (EuCAP), Lisbon, Portugal, 12-17 April 2015; pp. 1-2.

248. Bahramiabarghouei, H.; Porter, E.; Santorelli, A.; Gosselin, B.; Popović, M.; Rusch, L.A. Flexible 16 antenna array for microwave breast cancer detection. In Proceedings of the 2015 9th European Conference on Antennas and Propagation (EuCAP), Lisbon, Portugal, 12-17 April 2015; pp. 1-2.

249. Byrne, D.; Craddock, I.J. Time-domain wideband adaptive beamforming for radar breast imaging. IEEE Trans. Antennas Propag. 2015, 63, 1725-1735. [CrossRef]

250. Conceição, R.C.; Byrne, D.; Ghavami, N.; Smith, P.P.; Craddock, I. Spectral filtering in phase delay beamforming for multistatic UWB breast cancer imaging. In Proceedings of the 20159 th European Conference on Antennas and Propagation (EuCAP), Lisbon, Portugal, 12-17 April 2015; pp. 1-4. 
251. Khan, M.; Chatteqee, D. UWB microwave sensor array characterization for early detection of breast cancer. In Proceedings of the 2015 IEEE Applied Electromagnetics Conference (AEMC), Guwahati, India, 18-21 December 2015; pp. 1-2.

252. Salleh, M.; Hasmah, S.; Othman, M.A.; Ali, N.; Sulaiman, H.A.; Misran, M.H.; Aziz, A.; Abidin, M.Z. Microwave Imaging Technique Using UWB Signal For Breast Cancer Detection. ARPN J. Eng. Appl. Sci. 2015, 10, 723-727.

253. Li, Q.; Xiao, X.; Wang, L.; Song, H.; Kono, H.; Liu, P.; Lu, H.; Kikkawa, T. Direct extraction of tumour response based on ensemble empirical mode decomposition for image reconstruction of early breast cancer detection by UWB. IEEE Trans. Biomed. Circuits Syst. 2015, 9, 710-724. [CrossRef] [PubMed]

254. Yin, T.; Ali, F.H.; Reyes-Aldasoro, C.C. A robust and artifact resistant algorithm of ultra-wideband imaging system for breast cancer detection. IEEE Trans. Biomed. Eng. 2015, 62, 1514-1525. [CrossRef]

255. O'Loughlin, D.; Krewer, F.; Glavin, M.; Jones, E.; O'Halloran, M. Estimating average dielectric properties for microwave breast imaging using focal quality metrics. In Proceedings of the 2016 10th European Conference on Antennas and Propagation (EuCAP), Davos, Switzerland, 10-15 April 2016; pp. 1-5.

256. Song, H.; Kubota, S.; Xiao, X.; Kikkawa, T. Design of UWB antennas for breast cancer detection. In Proceedings of the 2016 International Conference on Electromagnetics in Advanced Applications (ICEAA), Cairns, QLD, Australia, 19-23 September 2016; pp. 321-322.

257. Medina, Y.; Augusto, M.; Paz, A.V. Microwave imaging for breast cancer detection: Experimental comparison of Confocal and Holography algorithms. In Proceedings of the 2016 IEEE ANDESCON, Arequipa, Peru, 19-21 October 2016; pp. 1-4.

258. Song, H.; Kono, H.; Seo, Y.; Azhari, A.; Xiao, X.; Kikkawa, T. Confocal imaging by turning antennas with CMOS integrated circuits for breast cancer detection. In Proceedings of the 2016 International Symposium on Antennas and Propagation (ISAP), Okinawa, Japan, 24-28 October 2016; pp. 920-921.

259. Abbosh, A.; Mohammed, B.; Bialkowski, K. Differential microwave imaging of the breast pair. IEEE Antennas Wirel. Propag. Lett. 2016, 15, 1434-1437. [CrossRef]

260. Bah, M.H.; Hong, J.S.; Jamro, D.A. UWB patch antenna and breast mimicking phantom design and implementation for microwave breast cancer detection using TIME REVERSAL MUSIC. Microw. Opt. Technol. Lett. 2016, 58, 549-554. [CrossRef]

261. Kwon, S.; Lee, H.; Lee, S. Image enhancement with Gaussian filtering in time-domain microwave imaging system for breast cancer detection. Electron. Lett. 2016, 52, 342-344. [CrossRef]

262. Li, Y.; Santorelli, A.; Coates, M. Comparison of microwave breast cancer detection results with breast phantom data and clinical trial data: Varying the number of antennas. In Proceedings of the 2016 10th European Conference on Antennas and Propagation (EuCAP), Davos, Switzerland, 10-15 April 2016; pp. 1-5.

263. Mozaffarzadeh, M.; Mahloojifar, A.; Orooji, M. Image enhancement and noise reduction using modified Delay-Multiply-and-Sum beamformer: Application to medical photoacoustic imaging. In Proceedings of the 2017 Iranian Conference on Electrical Engineering (ICEE), Tehran, Iran, 2-4 May 2017; pp. 65-69.

264. Ji, J.; Tong, K.F.; Al-Armaghany, A.; Leung, T.S. A feasibility study of elastography based confocal microwave imaging technique for breast cancer detection. Opt. Int. J. Light Electron Opt. 2017, 144, 108-114. [CrossRef]

265. Aydın, E.A.; Kaya Keleş, M. Breast cancer detection using K-nearest neighbors data mining method obtained from the bow-tie antenna dataset. Int. J. RF Microw. Comput.-Aided Eng. 2017, 27, e21098. [CrossRef]

266. Byrne, D.; Sarafianou, M.; Craddock, I.J. Compound radar approach for breast imaging. IEEE Trans. Biomed. Eng. 2017, 64, 40-51. [CrossRef] [PubMed]

267. Elahi, M.; Curtis, C.; Lavoie, B.; Glavin, M.; Jones, E.; Fear, E.; ÓHalloran, M. Performance of leading artifact removal algorithms assessed across microwave breast imaging prototype scan configurations. Comput. Med. Imaging Graph. 2017, 58, 33-44. [CrossRef]

268. Elahi, M.; Glavin, M.; Jones, E.; ÓHalloran, M. Adaptive artifact removal for selective multistatic microwave breast imaging signals. Biomed. Signal Process. Control 2017, 34, 93-100. [CrossRef]

269. KaramFard, S.S.; Asl, B.M. 2-stage Delay-Multiply-And-Sum beamforming for breast cancer detection using Microwave Imaging. In Proceedings of the 2017 Iranian Conference on Electrical Engineering (ICEE), Tehran, Iran, 2-4 May 2017; pp. 101-106.

270. Hossain, M.D.; Mohan, A.S. Cancer Detection in Highly Dense Breasts using Coherently Focused Time Reversal Microwave Imaging. IEEE Trans. Comput. Imaging 2017, 3, 928-939. [CrossRef] 
271. Kranold, L.; Hazarika, P.; Popović, M. Investigation of antenna array configurations for dispersive breast models. In Proceedings of the 2017 11th European Conference on Antennas and Propagation (EUCAP), Paris, France, 19-24 March 2017; pp. 2737-2741.

272. Mirza, A.F.; See, C.H.; Danjuma, I.M.; Asif, R.; Abd-Alhameed, R.A.; Noras, J.M.; Clarke, R.W.; Excell, P.S. An Active Microwave Sensor for Near Field Imaging. IEEE Sens. J. 2017, 17, 2749-2757. [CrossRef]

(C) 2020 by the authors. Licensee MDPI, Basel, Switzerland. This article is an open access article distributed under the terms and conditions of the Creative Commons Attribution (CC BY) license (http:/ / creativecommons.org/licenses/by/4.0/). 